Original Articles

\title{
Use of botanical insecticides for sustainable agriculture: Future perspectives
}

\author{
Estefânia V.R. Campos ${ }^{\mathrm{a}, \mathrm{b}}$, Patrícia L.F. Proença ${ }^{\mathrm{a}}$, Jhones L. Oliveira ${ }^{\mathrm{a}}$, Mansi Bakshic, \\ P.C. Abhilash ${ }^{\mathrm{c}}$, Leonardo F. Fraceto ${ }^{\mathrm{a}, *}$
}

a São Paulo State University - UNESP, Institute of Science and Technology, Sorocaba, SP, Brazil

b Department of Biochemistry, State University of Campinas, Campinas, SP, Brazil

${ }^{\mathrm{c}}$ Institute of Environment \& Sustainable Development, Banaras Hindu University, Varanasi 221005, India

\section{A R T I C L E I N F O}

\section{Keywords:}

Sustainable agriculture

Biodiversity

Green nanotechnology

Botanical pesticides

\begin{abstract}
A B S T R A C T
Recent decades have witnessed major growth in the use of agrochemicals worldwide, - for maximizing the food production for a rapidly growing human population. However, the indiscriminate use of these substances especially the pesticides has led to the accumulation of toxic residues in food, soil, air, and water, as well as the development of resistance in pests. Moreover, pesticides affect soil enzymes, which are essential catalysts that govern soil quality. In order to meet the food security, it is necessary to produce more food, sustainably and safely, in a diminishing area of available arable land and with decreased water resources. Given this situation, there is an increased interest in the use of alternative substances to synthetic agrochemicals that present less risk to the environment and human health while increasing the food safety. Promising results have been obtained using compounds derived from aromatic plants for the control of agricultural pests. Such compounds of botanical origin can be highly effective, with multiple mechanisms of action, while at the same time having low toxicity towards nontarget organisms. However, the large-scale application of these substances for pest control is limited by their poor stability and other technological issues. In this backdrop, the present work discusses perspectives for the use of compounds of botanical origin, as well as strategies employing the encapsulation techniques that can contribute to the development of systems for use in sustainable agricultural practices.
\end{abstract}

\section{Introduction}

Human population is increasing at an alarming rate (i.e., 70 million per year) and if this trend continues, there will be 10 billion people in the world by the end of the century (Gerland et al., 2014; Tilman et al., 2002; United Nations, 2013). In order to feed such a population, it will be necessary to double or even triple agricultural production in the coming years. Since most of the cultivable land is already being used, this growth must come from higher yields in the existing production areas (Archana Singh, 2014; Fountain and Wratten, 2013; Kumar, 2013; Tilman et al., 2002). With the advent of the Green Revolution, agriculture started to generate higher yields, although the growth in productivity of most crops has now stabilized (a phenomenon known as yield stabilization), and one of the main contributing reasons for this is the damage caused by pests and diseases (Archana Singh, 2014; Grassini et al., 2013). Approximately 67,000 species of organisms are known to affect agricultural crops, and without preventive protection using agrochemicals, $70 \%$ of agricultural production could be lost (Archana Singh, 2014; Donatelli et al., 2017; Ross and Lembi, 1985). Although the use of agrochemicals has benefited agricultural production, indiscriminate use (intensive and extensive) has led to many problems, including environmental damage (contamination of water, air and soil resources), toxicity to nontarget organisms, toxicity to humans associated with the presence of agrochemical residues in food, and decreased effectiveness of the chemicals following the development of pest resistance (Aktar et al., 2009; Fountain and Wratten, 2013; Kumar, 2012).

Agrochemicals can reach the soil due to direct applications, such as for weed control and following seed treatment, as well as indirectly by spraying of the aerial parts of plants, the falling of treated foliage or fruits, and the movement of contaminated water on the surface and within the soil profile (Chaplain et al., 2011; Chowdhury et al., 2008; Cycon et al., 2017; Gevao et al., 2000). Once accumulated in the soil, these chemicals can be transported by leaching and surface runoff and they can undergo chemical processes such as hydrolysis, photolysis, and chemical degradation, as well as they can interact with the living fraction of the soil (the microbiota) and be biodegraded (Arias-Estévez et al., 2008; Chaplain et al., 2011; Kookana et al., 1998; Meite et al., 2018; Salazar-Ledesma et al., 2018; Shaheen et al., 2017). As a result of these processes, pesticides and/or their metabolites (which may be

\footnotetext{
* Corresponding author at: São Paulo State University, Av. Três de Março, 511, Alto da Boa Vista, CEP 18087-180 Sorocaba, SP, Brazil.

E-mail address: leonardo@sorocaba.unesp.br (L.F. Fraceto).
} 


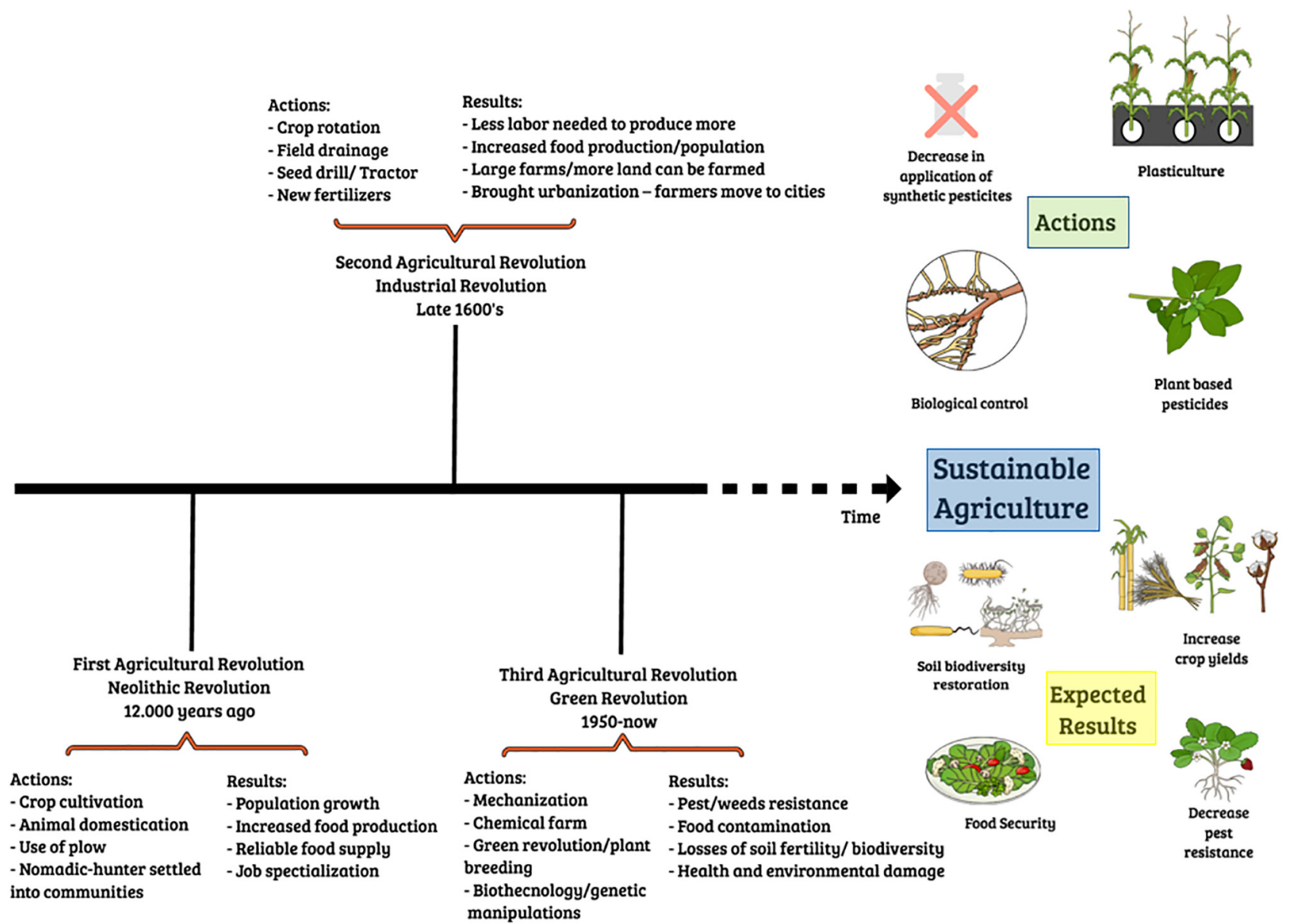

Fig. 1. Schematic representation of agricultural development and potential gains from implementation of sustainable agriculture.

more or less toxic than the parent compounds) can reach hydric resources (surface and subterranean waters), become bioaccumulated through the food chain, be completely mineralized, or persist for long periods in the soil (Chaplain et al., 2011; Gevao et al., 2000). The intensive use of agrochemicals increases their persistence in the soil and thereby negatively affecting the soil microbiota. The microorganisms that compose this microbiota respond in different ways to the different types of pesticides, and may exhibit increased or inhibited growth and metabolism (Chaplain et al., 2011; Chowdhury et al., 2008; Cycon et al., 2017). Many studies have shown that pesticides cause qualitative and quantitative changes in the soil microbiota (Duah-Yentumi and Johnson, 1986; Hartmann et al., 2015; Komorowicz et al., 2010), alteration of nitrogen cycling (Damin and Trivelin, 2011), changes in soil enzymatic activity, and disruption of the symbiosis between mycorrhizae and root nodules in legumes. These factors lead to alterations of soil fertility and, consequently, plant growth (Malik et al., 2017).

Since 2008, more than $80 \%$ of soybean and maize grown in the United States are genetically engineered. Corn seeds are modified in two genes: one kills insects that feed on seeds and the other allows seeds to tolerate glyphosate while soybeans contain only the gene that confers resistance to glyphosate. According Perry et al. (2016), farmers who used the insect-resistant seeds used significantly less insecticide (about $11.2 \%$ less when compared with to farmers who did not use genetically modified maize). It was observed also a reduction around $1.3 \%$ of herbicide applications. However, farmers who used soybean genetically modified seeds used $28 \%$ more herbicides than the farmers who did not use genetically modified seeds. These authors also attribute this increase to the proliferation of glyphosate-resistant weeds. Despite the decrease in insecticide use, continued growth in herbicide use poses a significant environmental problem as large doses of the chemicals can harm biodiversity and increase water and air pollution. (Kniss, 2017) evaluate the how mammalian toxicity of herbicides has changed in United States in the last 25 years especially regarding the widespread use of genetically modified crops. According to this author there is a strong evidence that herbicides applications has increased in maize, soybean and cotton genetically modified crops. Nevertheless, this author also found an increasing in herbicides uses in non-genetically modified crops (such as rice and wheat). These finding indicates that there is a general trend towards increased use of herbicides independent of the use of genetically modified plants. In addition, the authors suggested that the dependence of current agriculture on genetically modified crops and herbicides use has resulted in a decrease in the development of other potential solutions.

Soil degradation is now one of the greatest environmental challenges, especially in agriculture (Pimentel and Burgess, 2013; Squire et al., 2015). The intensification of agriculture after the Green Revolution resulted in widespread degradation of soils in the forms of erosion, compaction, pesticide contamination, loss of organic matter, increased salinity, and loss of biodiversity, among others (Kibblewhite et al., 2008; Schiefer et al., 2016; Turpin et al., 2017). Therefore, it is essential that sustainable agriculture should be able to recover soil quality by means of strategies such as the use of biopesticides and biofertilizers, crop diversity and rotation, and the use of microbial consortia, in order to meet the growing demand for food (Verma et al., 2015; Zhang et al., 2016). The search for effective and environmentally safe techniques for controlling pests has intensified, with the main strategies being biological control using natural enemies present in the field, as well as the use of natural products such as those derived from plants. Botanical pesticides offer a good alternative to traditional chemicals for use in crop protection systems (Bissinger and Roe, 2010; 
Nerio et al., 2010; Kumar, 2012; Fountain and Wratten, 2013; Kumar, 2013; Campos et al., 2014; Pavela and Benelli, 2016). A variety of different strategies can be adopted for the development of sustainable agriculture. Therefore, the present study considers the potential of botanical pesticides as tools in pest control, with the aim of maintaining the long-term productivity of crops, while at the same time reducing environmental degradation.

About 12,000 years ago, a new process of instrument manufacture began to develop, resulting in the Neolithic revolution (Fig. 1). Some of these neolithic societies began to sow plants and keep animals in captivity, in order to multiply them and use their products. After some time, these selected and exploited plants and animals were domesticated, and thus these predator societies were progressively transformed into societies of cultivators and breeders. This passage from predation to agriculture is known as the Neolithic Agricultural Revolution (Scanes, 2018). The second Agricultural Revolution (Fig. 1) refers to the period of change in the agriculture that occurred between the mid-1600s and the late 1800s. Before the revolution, the open-field system of cultivation was used which caused cattle overgrazing, uncontrolled breeding, and spread of animal diseases. Mechanization and scientific principles were adopted, which led to increased productivity and efficiency. As agricultural outputs became increasingly more efficient, fewer workers were required, more food was on hand, and industries cropped up as a result of the agricultural revolution (Demont et al., 2001; Hess, 2016). Technological innovations in agriculture to achieve higher productivity through the development of bio-engineered seeds that worked in conjunction with chemical fertilizers and agrochemicals, heavy irrigation and mechanization in the field to increase productivity was called the Green Revolution (Fig. 1). Although initially used to improve crop production, overuse of chemicals has now started affecting the environment and human health (Evenson, 2003; Pingali, 2012). These chemicals have drastic effects on non-target organisms and affect animal and plant biodiversity, aquatic as well as terrestrial ecosystems. In addition, one of the major problems of pesticide overuse is the development of resistant species to pesticides commonly used to control agricultural pests (Bernardes et al., 2015; Chowdhury et al., 2008; Kaur and Garg, 2014). Thus sustainable development represents in many ways a critique and contrast to the successes of the Green Revolution. In this way, sustainable agriculture is the way to feed the world (Caira and Ferranti, 2016; Martin-Guay et al., 2018).

Industrialized agriculture and sustainable agriculture (Fig. 1) differ in terms of the use of land and agrochemicals, crop yields, and environmental impacts. The traditional agricultural management model is characterized by high dependence on inputs of materials such as pesticides and fertilizers, many of which cause environmental contamination (Pretty and Pervez Bharucha, 2015; Seufert et al., 2012). The sustainable agriculture model is based on improved efficiency of the use of agrochemicals by means of integrated pest management (IPM), substitution of materials, and the application of alternative technologies with low energy consumption and plant/animal integration (Alam et al., 2016; Lechenet et al., 2014; Seufert et al., 2012).

\section{Botanical pesticides}

The main botanical pesticides are essential oils produced as secondary metabolites in plants. These oils play an important roles in the life cycles of plants, acting as defenses against pathogen and herbivore attacks, or attracting pollinators and seed disseminators (Isman, 2000a, 2006; Pavela and Benelli, 2016; Regnault-Roger et al., 2012). Essential oils (Fig. 2) are responsible for the different flavors and aromas of aromatic plants (Nagegowda, 2010). These oils consist of complex mixtures of volatile and lipophilic compounds, with typically around 20-60 substances, of which two or three are considered major compounds present at high concentrations, while the other substances are present at trace levels (Bakkali et al., 2008; Burt, 2004). The compounds present in the essential oils can be classified into two chemical groups, according to their metabolic synthesis pathways: (i) low molecular weight phenylpropanoids, and (ii) terpenoids (monoterpenes and sesquiterpenes). Monoterpenes are synthesized in the plastids via the methylerythritol phosphate pathway, while sesquiterpenes are synthesized in the cytosol via the mevalonate pathway (Aharoni et al., 2005; Nagegowda, 2010; Regnault-Roger et al., 2012).

Botanical pesticides, in the form of isolated substances or complex mixtures, exhibit a range of biological activities, acting as repellents, insecticides, fungicides, nematicides, and bactericides (Isman, 2006). Studies have found that in several species of mosquito, including species of agricultural importance, botanical pesticides inhibit food ingestion, growth at various stages of development, and egg laying (Aharoni et al., 2005; Nagegowda, 2010; Pavela, 2011; Regnault-Roger et al., 2012). However, there is poor understanding of the mode of action of these substances, which appear to differ according to the individual compounds (Table 1). In bacteria and fungi, the action of essential oils is generally associated with their ability to disrupt the cell walls and cytoplasmic membranes of the organisms, This results in cell lysis and loss of intracellular components, or increased absorption of inorganic phosphate $\left(\mathrm{PO}_{4}{ }^{3-}\right)$ and consequent leakage of potassium $\left(\mathrm{K}^{+}\right.$) (Devi et al., 2010; Lambert et al., 2001; Tian et al., 2012; Turgis et al., 2009). There is evidence that botanical pesticides can present different mechanisms of action in insects and mammals, acting especially in the nervous system, affecting $\gamma$-aminobutyric acid (GABA) gated chloride channels, acetylcholinesterase, nicotinic acetylcholine receptors (nAChR), octopamine and tyramine receptors, and sodium channels, among other possible mechanisms (Pavela and Benelli, 2016; Regnault-Roger et al., 2012).

Monoterpenes isolated from essential oils have been found to be capable of binding to ionotropic GABA receptors in insects, rodents, and other mammals. Positive allosteric modulators of mammalian $\mathrm{GABA}_{\mathrm{A}}$ receptors include camphor, carvone, linalool, menthol, and thymol, among other monoterpenes (García et al., 2006; Hall et al., 2004; Krasowski et al., 2002). Homozygous GABA receptors of Drosophila melonogaster were found to be positively modulated by thymol (Priestley et al., 2003). All of these compounds have been shown to increase the GABA-induced chloride current at recombinant GABA receptors in different models. In addition to receptors, botanical pesticides can affect enzymes present in the nervous system, such as acetylcholinesterase. Some compounds, such as geraniol, linalool, $\gamma$ terpinene, and fenchone have been observed to bind to the active site of the enzyme, resulting in reversible competitive inhibition. Others, such as camphor, estragole, and S-carvone have shown non-competitive inhibition, binding to the free enzyme or to the enzyme-substrate complex at locations different to the active site (Dickens and Bohbot, 2013; ElWakeil, 2013; Lambert et al., 2001; Ahmed et al., 2011).

In insects, tyramine and octopamine receptors are coupled to Gprotein and are important targets for botanical pesticides. Studies using Periplaneta americana showed that eugenol affects the octopaminergic system, leading to the activation of octopamine (a neuromodulator) receptors (Enan, 2001, 2005a,b). An increase in adenylate cyclase activity was observed at low doses of eugenol and octopamine, while high doses of eugenol decreased the activity of this enzyme. Similar to eugenol, compounds including carvacrol, $\alpha$-terpineol, pulegone, and 20 other monoterpenes were found to bind to the octopamine receptors of Periplaneta americana, with high sensitivity. Receptors for tyramine, which is a precursor of octopamine, were also involved in the mechanism of action of some monoterpenes, such as carvacrol, $\alpha$-terpineol, and thymol, in Drosophila melonogaster cells presenting tyramine receptors. Thymol acted to increase the intracellular cAMP levels, whereas carvacrol and $\alpha$-terpineol decreased this intracellular second messenger, hence modulating intracellular calcium levels (Enan, 2001, 2005a,b).

Botanical pesticides whose mechanisms of action involve GABA receptors may be more effective, due to the speed of the effect, since 


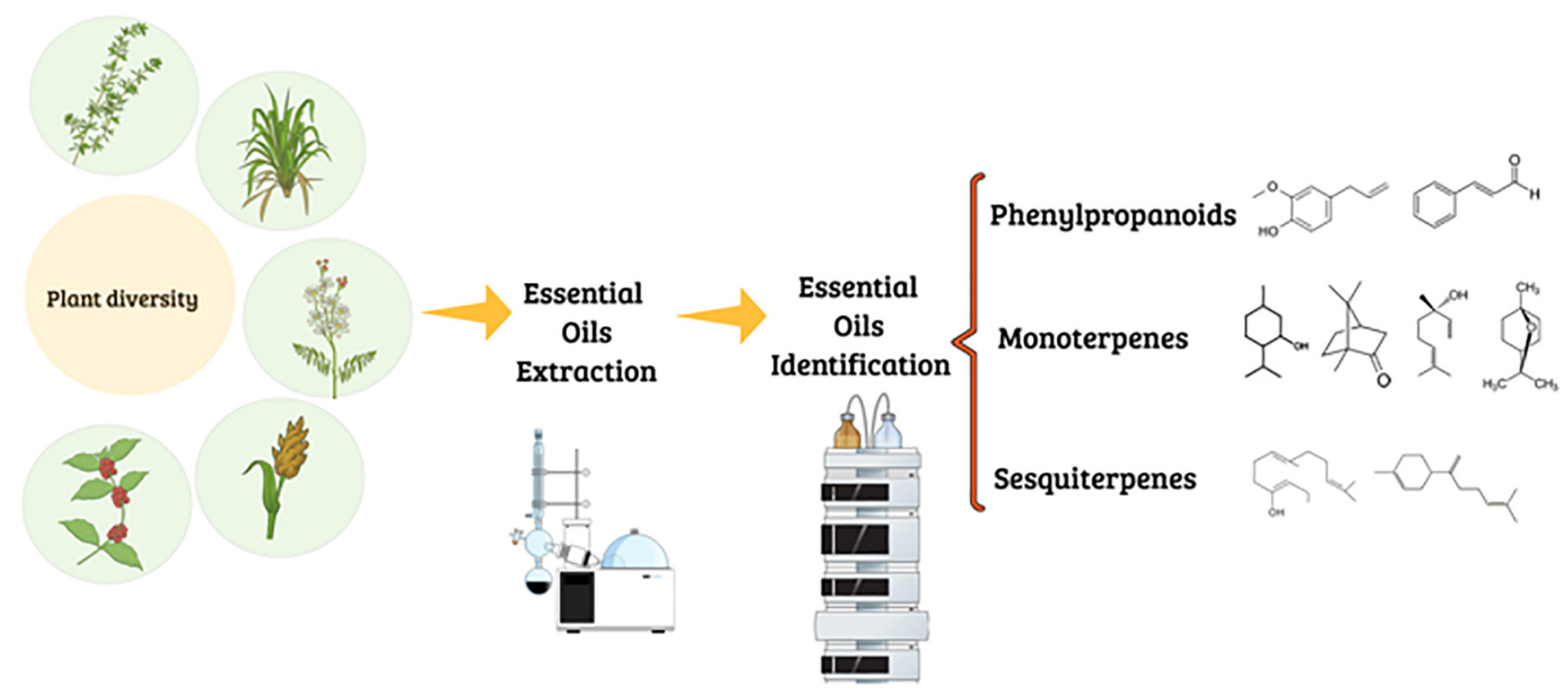

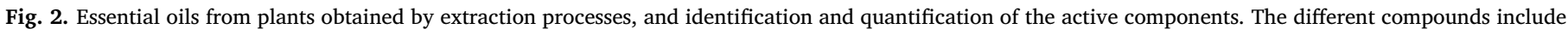
the phenylpropanoid, monoterpene, and sesquiterpene classes.

Table 1

Mechanisms of action of some botanical pesticides.

\begin{tabular}{|c|c|c|c|}
\hline Compound & Botanical species $^{\mathrm{a}}$ & Mechanism of action ${ }^{\mathrm{b}}$ & References \\
\hline Pyrethrin & Chrysanthemum cinerarifolium & Agonists of voltage-sensitive sodium channels (GABAergic system) & $\begin{array}{l}\text { Wakeling et al. (2012) and Soderlund and Bloomquist } \\
\text { (1989) }\end{array}$ \\
\hline Thujone & Artemisia absinthium & Reversible modulator of $\mathrm{GABA}_{\mathrm{A}}$ receptors & Höld et al. (2000) \\
\hline Thymol & Thymus vulgaris & Stimulates $\mathrm{GABA}_{\mathrm{A}}$ receptors & Enan (2005a) \\
\hline Azadirachtin & Azadirachta indica & Inhibits the activity of acetylcholinesterase & Senthil Nathan et al. (2008) \\
\hline Linalool & Aniba rosaeodora & Competitive and reversible inhibition of acetylcholinesterase activity & Perry et al. (2000) and Ryan and Byrne (1988) \\
\hline Carvacrol & Origanum vulgare & Binds to nicotinic acetylcholine receptors & Tong et al. (2013) \\
\hline Eugenol & Syzygium aromaticum & Stimulates octopamine receptors & Price and Berry (2006) \\
\hline Menthol & Mentha piperita & Positive allosteric modulator of the $\mathrm{GABA}_{\mathrm{A}}$ receptor & Hall et al. (2004) \\
\hline$\alpha$-Terpineol & Citrus sinensis & $\begin{array}{l}\text { Reduces intracellular levels of second messenger cAMP (tyramine } \\
\text { receptors) }\end{array}$ & Enan (2001) \\
\hline 1,8-Cineol & Rosmarinus officinalis & Antagonist of octopamine receptors & Dayan et al. (2009) and Fischer et al. (2013) \\
\hline Cinnamaldehyde & Cinnamomum zeylanicum & Antagonist of octopamine & Dayan et al. (2009) and Fischer et al. (2013) \\
\hline Nicotine & Nicotiana sp. & Agonist of acetylcholine & $\begin{array}{l}\text { Copping and Duke (2007) and Isman and Paluch } \\
\text { (2011) }\end{array}$ \\
\hline Rotenone & Derris sp. & Mitochondrial cytotoxin & $\begin{array}{l}\text { Copping and Duke (2007) and Isman and Paluch } \\
\text { (2011) }\end{array}$ \\
\hline Citronellal & Cymbopogon nardus & Antagonist of octopamine & Dayan et al. (2009) and Fischer et al. (2013) \\
\hline
\end{tabular}

these receptors are mainly present in the peripheral nervous systems of insects, especially at neuromuscular junctions. In contrast, those compounds that act on receptors attached to G-protein (octopamine and tyramine receptors) have lesser effects, due to the complex signaling cascades of these pathways (El-Wakeil, 2013; Ahmed et al., 2011).

Other botanical substances, such as pyrethrins, rotenone, nicotine, and azadirachtin, among others, have insecticidal activities that are well documented in the literature (Bennett and Wallsgrove, 1994; Campos et al., 2016; Isman, 2000a, 2006; Pascual-Villalobos and Robledo, 1998; Regnault-Roger, 1997). However, with increasing interest in pest control employing substances that are safer in the environment, recent research has shown that essential oils or their constituent compounds, such as carvacrol and linalool, are not only able to repel insects (Tambwe et al., 2014), but also present insecticidal action following direct contact or entry into the insect respiratory system (Beier et al., 2014). Both carvacrol and linalool have proven fungicidal activity against several important pathogens (Engel et al., 2017; Guimarães et al., 2015; Herman et al., 2016; Hsu et al., 2013; Keawchaoon and Yoksan, 2011; Müller et al., 2009; Peana et al., 2004a,b; Silva Brum et al., 2001; Tong et al., 2013).
It is already known that the performance of essential oils and/or their components may vary according to the susceptibility of a particular species, i.e., essential oils are not effective for all species of agricultural pests (Khani and Asghari, 2012; Khani and Rahdari, 2012; Lee et al., 2003; Negahban et al., 2007). In addition, the chemical composition as well as the functional groups (position and nature) present in the essential oils plays an important role in the insecticidal and/or repellent activity (Kumbhar and Dewang, 2001; Mossa, 2016). This biological activity can be potentiated by modifying the chemical structure of the monoterpenoids present in essential oils (Kumbhar and Dewang, 2001; Mossa, 2016). In this sense, the relationship between performance and chemical composition, regarding the importance of functional groups can be studied through biorational design of the derivatives (Kumbhar and Dewang, 2001; Mossa, 2016).

\section{Botanical pesticides: R\&D, gaps, and market}

Microorganisms are known to play a key role in soil quality and health. In this way, the microbial biomass as well as the enzymatic activity are potential indicators of soil quality, since they are directly 
correlated with the soil biology and for rapidly responding to changes due to anthropogenic and environmental action. Stimulating or inhibitory effects may be observed after the application of essential oils and/or their compounds alone, in microorganisms (Stamou et al., 2017; Vokou, 2007) and soil enzymes (Papatheodorou et al., 2014; Stamou et al., 2017). There may be an increase or decrease in the microbial population, alter the microbial community profile and influence the activity of various microbial taxa (Kadoglidou et al., 2011; Abdel Rasoul, 2012; Vokou et al., 2002). However, it has also been shown that these compounds affect the soil enzymes in a selective manner, i.e., at the recommended dose, have no effect on soil structure and microbial biomass (Papatheodorou et al., 2014; Spyrou et al., 2009). Thus, these compounds cause lower impacts to soil organisms and enzymatic activity when compared to chemical pesticides being then used to control agricultural pests.

Antonious (2003) evaluated the soil urease activity caused by pyrethrin and Neemix formulations. According to this author application of these compounds resulted in a transitional effect on urease activity. However, this effect was beneficial since they were neither drastic nor prolonged enough to be considered toxic to soil microorganisms. This author also found that the application of botanical insecticides could reduce the urea fertilizer mineralization to some extent. Stamou et al. (2017) evaluated the mutual effect of arbuscular mycorrhizal fungi (AMF) and essential oil in the soil microbial community. The results found that both AMF and essential oil operate as selective forces during fungal pre-symbiotic phase. Experiments carried out with essential oil only showed microbial community dominated by actinomycetes and micro eukaryotes while experiment with both treatments revealed the emergence of new microbial communities due to the divergent effects of both treatments. However, a synergistic effect of these treatments was observed for enzymatic activity of asparaginase and glutaminase. In this sense, the soil microbiota as well as soil quality can be benefited by the association of beneficial microorganisms and essential oils for sustainable agriculture. However, factors such as concentration, form of application, as well as application phase (in relation to the development of the microorganism) should be better studied in order not to harm the beneficial effects of this association.

In recent years, there is an exponential growth in the number of academic publications regarding the use of botanical pesticides as a tool for pest control, applying the integrated pest management (IPM) approach. Furthermore, many laboratories worldwide have intensified research into essential oils and their constituents, with the aim of exploiting their pesticidal properties (Grumezescu, 2017). However, despite these advances, there are still only few commercially available products based on plant essential oils or their isolated constituents (Table 2). According to Isman and Grieneisen (2014), the major factors limiting the wide scale exploitation of botanical pesticides are i) due to the lack of practically applicable results in many of the published studies ii) lack of the availability of good quality botanical pesticides at affordable prices; iii) strict legislation; iv) short persistence of the compounds in the environment, due to rapid degradation; v) extraction of oils from plants grown under different climatic conditions, resulting in different compositions in terms of active agents, with potentially weaker effects in pest control and likelihood of variability among batches.

Therefore, issue of sustainability of botanical resources represents one of the main barriers to advances in the commercial availability of these products. Production on a commercial scale requires a large biomass of the source plant, necessitating its production on an agricultural scale (Isman, 2006). However, the increasing demand for production of food and energy crops hinders the cultivation of plants containing essential oils, making it difficult to obtain sufficient quantities for commercial purposes, unless the plants are highly abundant in nature (Sola et al., 2014a). A further difficulty lies in the reproducibility of botanical pesticides, mainly due to natural genetic variations of the species, as well as different cultivation conditions (considering geography and climate, among other factors) (Ndakidemi et al., 2016). In addition to the problems of cultivation, a key issue in the marketing of botanical products concerns the confidence of agriculturalists. Since many botanical compounds do not show any immediate effects and also have low residual action, many potential users are reluctant to substitute conventional products by botanical pesticides (Isman et al., 2011).

Even if it is possible to resolve all the issues described above, current regulatory barriers also present a major obstacle to the commercialization of these naturally occurring substances. In much of the world, legislation makes no distinction between synthetic pesticides and biopesticides (including botanicals). As a result, these products need to pass through long and costly registration processes, often accompanied by expensive toxicological and environmental assessments (Pavela, 2014; Pavela and Benelli, 2016). Therefore, the fact that many of these products may be destined for use in organic agriculture and by small producers means that it is often not possible to obtain the financial resources required to cover the costly processes involved in registration of new products (Hernández-Moreno et al., 2013).

In this context, the successful exploitation of emerging technologies seems to offer a way to overcome many of the difficulties that hinder the large scale production and commercialization of the botanical pesticides (Pavela and Benelli, 2016). For example, plant biotechnology research shows that genetic manipulation of certain field crop species will make it possible to produce large quantities of natural compounds originally isolated from other plant species (Daviet and Schalk, 2010). The nano/microencapsulation of natural compounds in different matrices has been shown to be an effective way of overcoming stability problems, increasing the effectiveness of the compounds due to: i) increased solubility; ii) protection against premature degradation (by high temperatures, photodegradation, and biodegradation); and iii) increased residual activity due to sustained release (de Oliveira et al., 2014; Mossa, 2016). The wall material of nanoparticulate system is selected according to the physicochemical properties of the active agent and required usage of the final formulation. However, according Kah and Hofmann (2014), among the different nanoparticulate system produced for agricultural applications, polymeric nanoparticles are those with greatest potential for development and practical application in agriculture. For this purpose, polysaccharides represent very attractive molecules, as they are biocompatible, biodegradable, low cost and high availability and can undergo various chemical modifications (Campos et al., 2015; Posocco et al., 2015; Raemdonck et al., 2013). Currently, nanotechnology has been shown to be a potential tool in the field of agricultural entomology (Kumar et al., 2017). Companies are already involved in the development of nanoformulations, for example, Syngenta started marketing the Karate ${ }^{\circledR}$ ZEON that is a broad-spectrum pesticide consisting of the insecticide lambda-cyhalothrin nanoencapsulated to regulate the insect population in rice, peanut, cotton and soybean crops. Many nanoformulations loading botanical pesticides has proven biological activity against pre and post harvest crop pests (Ebadollahi et al., 2017; Khoobdel et al., 2017; Negahban et al., 2014, 2012; Yang et al., 2009). In addition, progress has been also made in unblocking the marketing of products based on botanical pesticides. The recent classification of some botanical products as "low risk" by the European Food Safety Authority has contributed to decreasing the regulatory requirements for these products (Marchand, 2015).

\section{Botanical insecticides and nanotechnology: is it a real new possibility?}

It is increasingly accepted that traditional approaches to integrated pest management (IPM) are insufficient to combat pests and increase food productivity, and that there are adverse effects of intensive and extensive use of pesticides on animal and human health, nontarget organisms, and soil fertility. Alternative options have been sought to 
Table 2

Examples of commercially available products based on botanical pesticides.

\begin{tabular}{|c|c|c|c|}
\hline Active ingredient & Application & Commercial product & Company \\
\hline \multirow[t]{10}{*}{ Oil of neem (Azadirachtin) } & Insecticide & Margosom $^{\circledast}$ & Agri Life (India) \\
\hline & & AZA-Direct $\mathrm{R}^{\circledast}$ & Gowan Company (USA) \\
\hline & & AzeraTM ${ }^{\circledast}$ & MGK (USA) \\
\hline & & Azamax $^{\circledast}$ & UPL Ltda. (Brazil) \\
\hline & & Molt-X & BioWorks Inc. (USA) \\
\hline & & Neemix $4.5^{\circledast}$ & Certis (USA) \\
\hline & & Azatin $\mathrm{XL}^{\oplus}$ & OHP Inc. (USA) \\
\hline & & NeemAzal $\mathrm{T} / \mathrm{S}^{\circledast}$ & Trifolio-M (Germany) \\
\hline & & Fortune Aza 3\%EC ${ }^{\circledast}$ & Fortune Biotech (USA) \\
\hline & & Shubhdeep NeemOil ${ }^{\circledast}$ & King AgroFood (India) \\
\hline \multirow[t]{4}{*}{ Essential oil of garlic (Allium sativum L.) } & Insecticide & AjoNey ${ }^{\circledast}$ & I.H.N. (Mexico) \\
\hline & & EcoA-Z ${ }^{\circledast}$ & EcofloraAgro (Colombia) \\
\hline & & $\mathrm{L}^{\prime} \mathrm{EcoMix}{ }^{\circledast}$ & \\
\hline & & CapsiAlil $^{\circledast}$ & \\
\hline \multirow[t]{3}{*}{ Citrus sinensis L. oil (limonene and linalool) } & Insecticide/repellent & Demize EC ${ }^{\circledast}$ & Paragon Professional Pes \\
\hline & & & Control Products (USA) \\
\hline & & Prev-Am ${ }^{\circledast}$ & Oro Agri SA Ltd. (South Africa) \\
\hline Essential oil of thyme (Thymus vulgaris) & Insecticide/repellent & EcoVia WD ${ }^{\oplus}$ & Rockwell Labs Ltd. (USA) \\
\hline \multirow[t]{2}{*}{ Rotenone } & Insecticide & 5.\% Rotenone $\mathrm{ME}^{\circledast}$ & Beijing Kingbo Biotech Ltd. (China) \\
\hline & & Rotenone Dust ${ }^{\circledR}$ & Bonide Products Inc. (USA) \\
\hline \multirow[t]{3}{*}{ Nicotine (Nictiana tabacum L.) } & Insecticide & Nico Dust ${ }^{\circledast}$ & Nico Orgo Manures (India) \\
\hline & & Nico Neem ${ }^{\circledast}$ & \\
\hline & & $10 \%$ Nicotine AS $^{\circledast}$ & Beijing Kingbo Biotech Ltd. (China) \\
\hline Carvacrol/essential oil of oregano (Origanum vulgare) & Insecticide/animal feed supplement & By-O-reg + ${ }^{\oplus}$ & By-O-reg + (USA) \\
\hline
\end{tabular}

combat these problems, by developing pesticides that are more effective and do not persist in the environment (Arora and Mishra, 2016; Chandler et al., 2011; Park and Tak, 2016; Parsa et al., 2014). In order to reduce the adverse effects of conventional pesticides, plant-based biopesticides (such as essential oils) can be employed as an alternative or complementary tools in integrated pest management, benefiting from their desirable characteristics, as discussed above (Archana Singh, 2014; Bakkali et al., 2008; Isman, 2000b; Pavela and Benelli, 2016; Regnault-Roger et al., 2012). However, problems related to low aqueous solubility, high volatilization rates, and oxidation when exposed to the environment need to be resolved before these compounds can be employed in integrated pest management (Pavela and Benelli, 2016; Regnault-Roger et al., 2012).

The combination of two or more alternative pest control methods in production systems can enhance the effects and extend the range of target organisms, affecting different species or different stages of development of the same species. The use of botanical pesticides in association with bioinsecticides based on microorganisms offers a promising technique for the control of agricultural pests. In this approach, botanical pesticides cause stress in pests, hence facilitating their attack by disease organisms, whose toxins act more rapidly and consequently increase the mortality rates of the pests (Ansari et al., 2012; Ezhil Vendan, 2016; Raja, 2013; Wezel et al., 2014).

Among alternative methods, nanotechnological techniques can provide effective tools to overcome many difficulties. Benefits include protection of the compounds against degradation and losses by volatilization, easier handling, sustained release, and specific targeting of the active agents (Bilia et al., 2014; de Oliveira et al., 2014; Donsì et al., 2014; Marques, 2010; Pavela and Benelli, 2016; Regnault-Roger et al., 2012; Werdin González et al., 2014). In addition, such nanoformulations can be more effective than non-encapsulated substances (Anjali et al., 2012, 2010; Werdin González et al., 2014).

There has been a steady increase in published studies concerning the encapsulation of essential oils and/or their constituents in matrices including natural or synthetic polymers, lipids, and proteins, among others, according to the desired characteristics (Chen et al., 2009, 2015; de Oliveira et al., 2014; Gabriel Paulraj et al., 2017; Guimarães et al., 2015; Keawchaoon and Yoksan, 2011; Negahban et al., 2007, 2012, 2014; Yang et al., 2009). However, it should be noted that most of these studies have focused on the development of methods for the encapsulation of these compounds for food and pharmaceutical purposes (Pavela and Benelli, 2016; Rodríguez et al., 2016).

Synergistic effects obtained using combinations of different compounds can result in enhanced biological activity, compared to the activities observed for the individual compounds. The use of this strategy can enable application of lower dosages of the active agents, hence reducing both the cost of pest management and the environmental risks (Akhtar and Isman, 2013). Furthermore, the use of mixtures of compounds is less likely to lead to resistance and behavioral adaptation of insects (Akhtar and Isman, 2013; Pavela and Benelli, 2016). However, there are few reports concerning the action of different essential oils and/or their major components in the control of agricultural pests (Koul et al., 2013; Kumrungsee et al., 2014).

Although the combination of nanotechnology and botanical pesticides could be a promising tool for integrated pest management, further studies are required in relation to i) the use of encapsulation technology to encapsulate mixtures of different essential oils and/or their constituents; ii) the toxicological evaluation of nanoformulations, including effects on nontarget organisms; iii) effects of sublethal concentrations on target and nontarget organisms; iv) regulation of the use of nanomaterials and botanical pesticides in agriculture; v) selection of natural matrices for the production of nanoparticles and scalable nanoformulations; vi) comparative cost-benefit studies of nanoformulations and current commercial formulations; and (vii) evaluation of the fate and behavior of nanoformulations in the environment (Archana Singh, 2014; Fraceto et al., 2016; Isman and Grieneisen, 2014; Regnault-Roger et al., 2012; Servin and White, 2016).

Nanotechnology is described by the European Union as one of the six key technologies required for global sustainable development (European, 2012). It has been used in many branches of science, including pharmaceutical sciences, materials science, physics, chemistry, and medicine. In agriculture, there have been advances in nanotechnology applied in animal husbandry, insect control, and soil treatment (Chen and Yada, 2011; Salamanca-Buentello et al., 2005), as well as in the production, storage, processing, packaging, and transportation of agricultural products (Campos et al., 2014; Fraceto et al., 2016; Mukhopadhyay, 2014; Sekhon, 2014).

Nanotechnology can provide many benefits in sustainable agriculture (Chaudhary and Misra, 2017; Kumar et al., 2017; Prasad et al., 2017), including i) control of pests and diseases using nanoformulations 
that enable the sustained release of pesticides, improving their effectiveness and decreasing the concentrations required to achieve the desired effects; ii) sustained release of fertilizers to increase plant growth while reducing losses in runoff and decreasing water pollution problems such as eutrophication; iii) nanoparticle-mediated transfer of genes or DNA, assisting in the development of species resistant to pests and/or diseases; iv) use of nanomaterials to develop biosensors able to detect signs of diseases and/or predators, as well as identification of lack of nutrients and water; and v) new economically viable methods for the removal of pollutants from the soil and for water treatment (Araújo et al., 2015; Duhan et al., 2017; Fraceto et al., 2016; Iavicoli et al., 2017; Mukhopadhyay, 2014; Nair et al., 2010; Rai and Ingle, 2012; Sekhon, 2014; Torney et al., 2007; Verma, 2017).

Although there are various uncertainties regarding the use of nanotechnology and botanical pesticides in agriculture, cordial efforts should be made to convince the policy makers to seriously provide a market for such products by reducing many existing regulatory barriers (Amenta et al., 2015; Chandler et al., 2011; Jain et al., 2016; Sola et al., 2014b). In nanotechnology, the uncertainties are not related to the risks themselves, but the impossibility of calculating them (dos Santos and Gottschalk Nolasco, 2017; Pyrrho and Schramm, 2012). There are risks associated with nanotechnology in a complex and yet difficult to define scenario, but which, however, cannot be underestimated (Maynard, 2014; Stokes, 2013). Among them, we can emphasize the identification and management of the impacts of nanomaterial during the production chain; monitoring the cycle of persistent nanoparticles in the environment; and the complexity in the definition of acceptable levels of particles present in working conditions, environmental exposure and consumer of nanoproducts (Simone et al., 2009; Strand and Kjølberg, 2011; Tavares et al., 2015). Within this context, there is a question: what are the global strategic directions for a specific regulation for the use of nanotechnology? To date, there is no specific international regulation for commercially available products incorporating nanoparticles at some stage of industrial processing. Another point to be made is the lack of reliable international standard protocols for assessing the human and environmental toxicity of nanoparticles (dos Santos and Gottschalk Nolasco, 2017; Retzbach and Maier, 2015; Stokes, 2013; Strand and Kjølberg, 2011).

Due to the improvement in the quality and cost-effectiveness of nanotechnological products and processes, as well as the social benefits added to this technology, companies have developed strategic business plans and policies in research, development and innovation with the aim of bringing industrial competitive advantages in several areas (dos Santos and Gottschalk Nolasco, 2017; Riccardi, 2015). Importantly, effective cooperation is needed between academic research institutions and botanical pesticide producers in order to put into practice the results obtained at the laboratory scale. This is one of the keys to the success of integrated pest management, as both nanotechnology and biopesticides are tools that can be used in the development of sustainable agriculture, with the aim of providing significant improvements in food quality and safety, human health, and environmental preservation (Bilia et al., 2014; Pavela and Benelli, 2016; RegnaultRoger et al., 2012).

In addition to the nanotechnology associated with botanical pesticides, other technologies have been widely used in sustainable agriculture with the aim of reducing the population of insects that attack crops, such as the use of biological insecticides. Biological insecticides are excellent alternatives to bypass the environmental pollution derived from chemical insecticides, besides providing the most selective control of insects (Bravo et al., 2015; Narva et al., 2014). For the biological control of insect pests, the bacterium Bacillus thuringiensis, 1915 is considered the most interesting species being characterized by the production of protein crystals during sporulation, which have insecticidal activity (Proteins Cry) with high specificity against insect larvae of several orders. Transgenic cultures expressing Bt proteins require fewer applications of pesticides, reduce production costs, provide selectivity and specificity against target pests, and natural enemies (Bravo et al., 2015; Narva et al., 2014; Savini and Fazii, 2016). However, in spite of these advantages, there is currently great concern for the widespread use of Bt crops since they can accelerate the selection of resistant organisms in target pest populations (Niu et al., 2016; Vachon et al., 2012). In this sense, the association of bio-insecticides, both botanical and biological, may be potential tools in the control of agricultural pests in sustainable agriculture.

As highlighted here, the nanoencapsulation and sustained release of botanical pesticides has becoming a promising strategy to efficiently protect these compounds from premature degradation, thereby increasing their biological activity as well as reducing negative impacts on the environment. It is believed that in the near future, the sustained release of botanical pesticides will become a key tool for sustainable agriculture, aimed at improving agricultural production in order to produce sufficient food for the growing world population. In addition, the use of these nanoformulations aims to reduce environmental impacts and reduce risks to human and animal health. Thus, efficient management of agricultural pests with these nanoformulations will result in less use of bioactive molecules to control pests and consequently reduce several problems associated with the intensive use of synthetic agrochemicals, as previously mentioned.

\section{Future trends in sustainable agriculture}

The use of synthetic pesticides remains the principal technique for the control of pests and diseases in conventional agriculture, but it is acknowledged that agricultural production will be seriously threatened if sustainable techniques are not adopted. Many studies have shown that the intensive use of synthetic chemicals leads to irreversible damage to the structure and ecology of soil (Dabrowski et al., 2014; Saruchi et al., 2016), with negative effects on the microbiota (Asad et al., 2017; Bending et al., 2007; Yang et al., 2017). In contrast, there have been few studies and little is known concerning the impacts of botanical pesticides on soil microbiota (Fig. 3). It is mistakenly believed that since botanical pesticides are obtained from natural sources, they are therefore not toxic towards nontarget organisms and are always safer than synthetic pesticides (Rousidou et al., 2013; Spyrou et al., 2009).

Botanical pesticides typically exhibit broad spectrum antimicrobial activity, in most cases being nonselective, so they can potentially affect the soil microbiota population (Bhat et al., 2012; Conti et al., 2014; George et al., 2010; Spyrou et al., 2009). Nonetheless, as discussed earlier, these compounds offer considerable advantages, compared to the synthetic compounds currently used, and are promising for use in sustainable agriculture (Chowdhury et al., 2015; Dar et al., 2014; Dubey et al., 2010; Karani et al., 2017; Khaliq et al., 2014; Xu et al., 2015). Their rapid breakdown in the environment, together with low accumulation in the soil organic matter, can help to decrease the degradation of agricultural soils (Ansari et al., 2012; Archana Singh, 2014; Blázquez, 2014; Carrubba and Catalano, 2009; Pavela and Benelli, 2016; Raja, 2013). Botanical pesticides have been shown to provide effective control of different species of agricultural pests, in many cases being more effective than synthetic chemicals, due to their varied mechanisms of action (Sola et al., 2014a,b; Tambwe et al., 2014; Oliveira et al., 2017; Štefanidesová et al., 2017). An important point is that the formulation of new commercial products (using, for example, nanotechnological techniques) could further enhance the performance of these natural compounds, reducing both the dosages required and their toxicity towards nontarget organisms, especially the soil microbiota (Chhipa, 2017; de Oliveira et al., 2014; Mattos et al., 2017; Mossa, 2016).

Although nanotechnological materials have been shown to provide superior performance in many areas of science, the processes used to produce them can result in the generation of hazardous wastes, while the raw materials may be non-renewable resources (Duhan et al., 2017; 


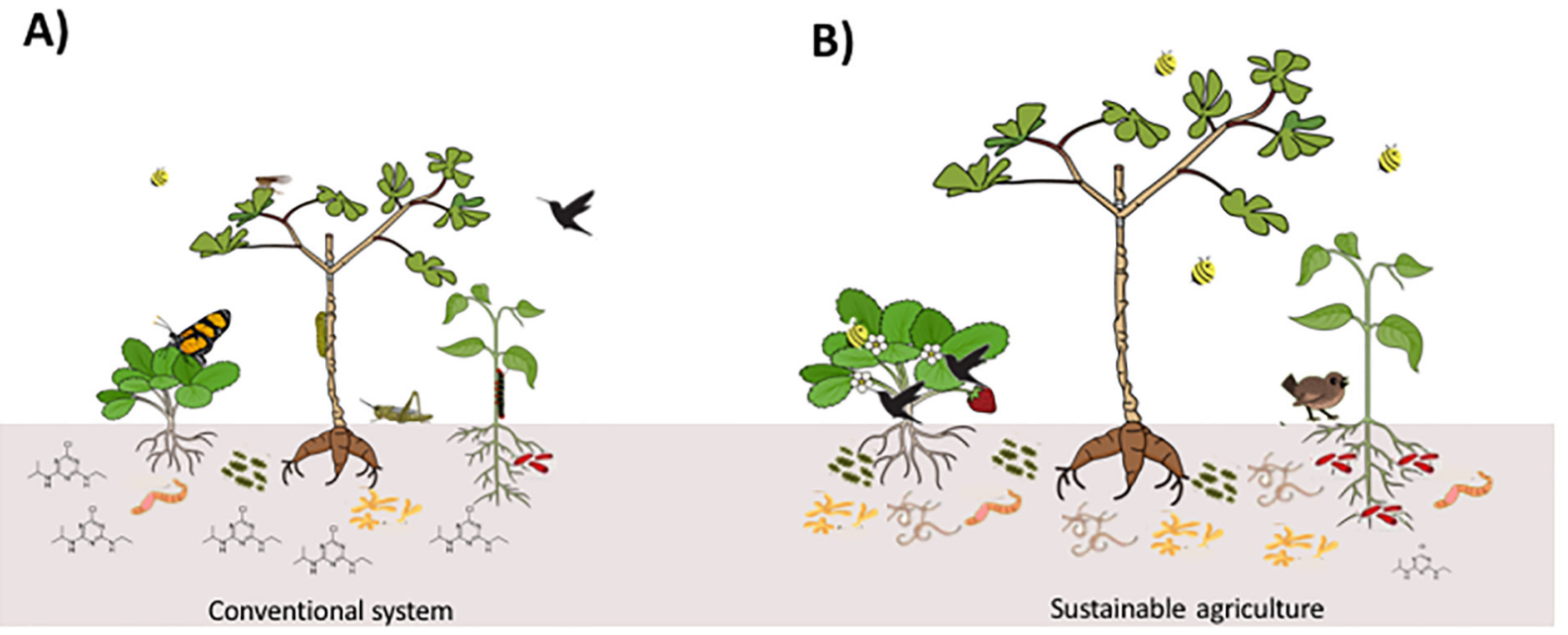

Fig. 3. Representation of a conventional agricultural system (A), based on the use of synthetic chemical compounds to control pests, with the development of pest resistance and decrease in the soil microbiota. (B) A sustainable agricultural system based on biological pest control, use of botanical insecticides/repellents, and application of new technologies. This scheme highlights the diversity of the soil microbiota, which is essential in sustainable agricultural practices, as well as potential improvements in plant development and consequently in food production.

Iavicoli et al., 2017; Mishra et al., 2017; Sinha et al., 2017). Hence, there have been considerable efforts to reduce the generation of toxic wastes and their disposal in the environment, as well as to develop production methods that are more energy efficient, in compliance with the principles of green chemistry. The aim of green nanotechnology (the combination of nanotechnology and the practices of green chemistry) is to develop and manufacture safer nanomaterials with zero or minimal generation of hazardous waste (de la Guardia, 2014; Lu and Ozcan, 2015; Nath and Banerjee, 2013; Pleissner, 2017). Green nanotechnology is one of the keys to successful implementation of sustainable agriculture in the 21st century, and has three basic principles: i) use of biocompatible and nontoxic solvents; ii) use of natural raw materials; and iii) use of energy efficient processes (de la Guardia, 2014; Lu and Ozcan, 2015; Nath and Banerjee, 2013).

For applications in sustainable agriculture, sustained release systems should preferably be manufactured using natural biodegradable polymers, instead of the synthetic polymers. Natural polysaccharides such as alginate, chitosan, and cyclodextrins, among others, have been extensively studied for the production of sustained release systems for use in agriculture, since they are biodegradable, biocompatible, and present low toxicity towards mammals (Campos et al., 2014). Chitosan is used in agriculture for the management of biotic and abiotic stress (Sharp, 2013; Wang et al., 2015; Xing et al., 2015). In addition to antimicrobial activity, chitosan is believed to enhance the systemic resistance of plants against pathogens (Katiyar1 et al., 2014; Sharp, 2013; Xing et al., 2015), and also to increase and regulate the growth, development, and yield of crops (Wang et al., 2015), and stimulate certain soil microorganisms (Cretoiu et al., 2013; Kamari et al., 2011).

Nanostructured systems can also be used to resolve a major issue in sustainable agriculture, namely the presence of contaminants in the soil, by detecting, monitoring, and removing these substances. This is especially important due to losses of productive agricultural areas following extensive soil degradation. The adoption of more sustainable agricultural practices is the only viable way of increasing productivity without causing negative impacts in the environment and on human health, and the use of botanical pesticides in agricultural systems can contribute to this goal. Further advantages could be gained by implementing techniques employing botanical pesticides in combination with nanomaterials produced in accordance with the principles of green chemistry. These promising systems offer effective and ecologically more sustainable ways for reducing the pest attack and consequently maximizing crop productivity. Nonetheless, it is clear that further work will be needed to obtain a better understanding of the fate and behavior of these materials in the environment.

To make the nanoencapsulated botanical pesticides closer to application in field condition, some issues need to be addressed. Studies involving the toxicity of these systems for humans, soil microorganisms and plants need to be better studied and understood in order to predict the possible toxic effects of these systems when they are deposited in the ecosystem. In addition studies focused on the elucidation of how these systems behave in relation to climatic changes, soil composition and structure, interaction/absorption and translocation in plants are of extreme importance to understand how these nanoformulations behave under different conditions and with different degrees of severity. As for example, these nanoformulations will behave in the same way in a tropical climate when compared to a temperate climate? It is worth mentioning that these studies cannot be limited only in laboratory scale, through in vitro tests. After obtaining satisfactory results in vitro, these studies are expected to be carried out under field conditions in small scale or in greenhouses, in order to bring these products closers to commercialization.

Another important fact that needs to be analyzed by future studies in the sustained release of botanical pesticides is the association of two different compounds in the same nanoparticulate system. These compounds may be derived from the essential oil of the same or different species. It is already known that the association of different compounds originating from essential oils may have additive, synergistic or antagonistic effects in a particular pest (Akhtar and Isman, 2013; Singh et al., 2009; Tak and Isman, 2017; Yang et al., 2017). However, these studies were largely performed only with non-encapsulated botanical pesticides. It is of great importance to analyze if the nanoencapsulation of these compounds, as well as the sustained release of them do not alter the effect patterns in the pests. As for example, two compounds which exhibit antagonistic effects when associated may have synergistic or additive effects when nanoencapsulated? Synergistic effects between botanical pesticides are quite promising for the application of these compounds in agriculture. Since potentiation of the effect results in the use of lower concentrations of these compounds for the control of pests and, consequently, would delay further the emergence of species resistant to botanical pesticides.

Finally, another trend in the field of nanotechnology that should be widely studied for agricultural applications is the development of "intelligent" sustained release systems (Hussain, 2017), which change the pattern of release of the substance according to a given stimulus. In agriculture, for example, release systems that are sensitive to changes in $\mathrm{pH}$, salinity, temperature, and others can be strong candidates for 
increasing agricultural productivity.

\section{Acknowledgments}

The authors are grateful for the financial support provided by the São Paulo State Research Foundation (FAPESP, grants \#2014/20273-4, \#2014/20286-9, and \# 2015/15617-9).

\section{References}

Abdel Rasoul, Mona A., 2012. Evaluation of antibacterial properties and biochemical effects of monoterpenes on plant pathogenic bacteria. Afr. J. Microbiol. Res. 6 http://dx.doi.org/10.5897/AJMR12.118.

Aharoni, A., Jongsma, M., Bouwmeester, H., 2005. Volatile science? Metabolic engineering of terpenoids in plants. Trends Plant Sci. 10, 594-602. http://dx.doi.org/ 10.1016/j.tplants.2005.10.005.

Ahmed, Sohail, Hussain, Abid, Zafar, Mazhar Iqbal, Riaz, Muhammad Asam, Shahid, Muhammad, 2011. Evaluation of Plant Extracts on Mortality and Tunneling Activities of Subterranean Termites in Pakistan. INTECH Open Access Publisher.

Akhtar, Y., Isman, M.B., 2013. Plant natural products for pest management: the magic of mixtures. In: Ishaaya, I., Palli, S.R., Horowitz, A.R. (Eds.), Advanced Technologies for Managing Insect Pests. Springer, Netherlands, pp. 231-247. http://dx.doi.org/10. 1007/978-94-007-4497-4 11

Aktar, M.W., Sengupta, D., Chowdhury, A., 2009. Impact of pesticides use in agriculture: their benefits and hazards. Interdiscip. Toxicol. 2, 1-12. http://dx.doi.org/10.2478/ v10102-009-0001-7.

Alam, M.Z., Crump, A.R., Haque, M.M., Islam, M.S., Hossain, E., Hasan, S.B., Hasan, S.B., Hossain, M.S., 2016. Effects of integrated pest management on pest damage and yield components in a rice agro-ecosystem in the Barisal Region of Bangladesh. Front. Environ. Sci. 4. http://dx.doi.org/10.3389/fenvs.2016.00022.

Amenta, V., Aschberger, K., Arena, M., Bouwmeester, H., Botelho Moniz, F., Brandhoff, P., Gottardo, S., Marvin, H.J.P., Mech, A., Quiros Pesudo, L., Rauscher, H., Schoonjans, R., Vettori, M.V., Weigel, S., Peters, R.J., 2015. Regulatory aspects of nanotechnology in the agri/feed/food sector in EU and non-EU countries. Regul. Toxicol. Pharmacol. 73, 463-476. http://dx.doi.org/10.1016/j.yrtph.2015.06.016.

Anjali, C., Sharma, Y., Mukherjee, A., Chandrasekaran, N., 2012. Neem oil (Azadirachta indica) nanoemulsion - a potent larvicidal agent against Culex quinquefasciatus. Pest Manage. Sci. 68, 158-163. http://dx.doi.org/10.1002/ps.2233.

Anjali, C.H., Sudheer Khan, S., Margulis-Goshen, K., Magdassi, S., Mukherjee, A., Chandrasekaran, N., 2010. Formulation of water-dispersible nanopermethrin for larvicidal applications. Ecotoxicol. Environ. Saf. 73, 1932-1936. http://dx.doi.org/ 10.1016/j.ecoenv.2010.08.039.

Ansari, M.S., Ahmad, N., Hasan, F., 2012. Potential of biopesticides in sustainable agriculture. In: Malik, A., Grohmann, E. (Eds.), Environmental Protection Strategies for Sustainable Development, Strategies for Sustainability. Springer, Netherlands, pp. 529-595. http://dx.doi.org/10.1007/978-94-007-1591-2_17.

Antonious, G.F., 2003. Impact of soil management and two botanical insecticides on urease and invertase activity. J. Environ. Sci. Health Part B 38, 479-488. http://dx. doi.org/10.1081/PFC-120021667.

Araújo, R., Castro, A.C.M., Fiúza, A., 2015. The use of nanoparticles in soil and water remediation processes. Mater. Today Proc. 2, 315-320. http://dx.doi.org/10.1016/j. matpr.2015.04.055.

Archana Singh, S.K., 2014. Biopesticides for integrated crop management: environmental and regulatory aspects. J. Biofertil. Biopestic. 05. http://dx.doi.org/10.4172/2155$6202.1000 \mathrm{e} 121$.

Arias-Estévez, M., López-Periago, E., Martínez-Carballo, E., Simal-Gándara, J., Mejuto, J.C., García-Río, L., 2008. The mobility and degradation of pesticides in soils and the pollution of groundwater resources. Agric. Ecosyst. Environ. 123, 247-260. http:// dx.doi.org/10.1016/j.agee.2007.07.011.

Arora, N.K., Mishra, J., 2016. Prospecting the roles of metabolites and additives in future bioformulations for sustainable agriculture. Appl. Soil Ecol. 107, 405-407. http://dx. doi.org/10.1016/j.apsoil.2016.05.020.

Asad, M.A.U., Lavoie, M., Song, H., Jin, Y., Fu, Z., Qian, H., 2017. Interaction of chiral herbicides with soil microorganisms, algae and vascular plants. Sci. Total Environ. 580, 1287-1299. http://dx.doi.org/10.1016/j.scitotenv.2016.12.092.

Bakkali, F., Averbeck, S., Averbeck, D., Idaomar, M., 2008. Biological effects of essential oils ? A review. Food Chem. Toxicol. 46, 446-475. http://dx.doi.org/10.1016/j.fct. 2007.09.106.

Beier, R.C., Byrd, J.A., Kubena, L.F., Hume, M.E., McReynolds, J.L., Anderson, R.C. Nisbet, D.J., 2014. Evaluation of linalool, a natural antimicrobial and insecticidal essential oil from basil: effects on poultry. Poult. Sci. 93, 267-272. http://dx.doi.org/ 10.3382/ps.2013-03254.

Bending, G.D., Rodríguez-Cruz, M.S., Lincoln, S.D., 2007. Fungicide impacts on microbial communities in soils with contrasting management histories. Chemosphere 69 , 82-88. http://dx.doi.org/10.1016/j.chemosphere.2007.04.042.

Bennett, R.N., Wallsgrove, R.M., 1994. Secondary metabolites in plant defence mechanisms. New Phytol. 127, 617-633. http://dx.doi.org/10.1111/j.1469-8137.1994. tb02968.x.

Bernardes, M.F.F., Pazin, M., Pereira, L.C., Dorta, D.J., 2015. In: Impact of Pesticides on Environmental and Human Health, http://dx.doi.org/10.5772/59710.

Bhat, B.A., Bhat, I.A., Vishwakarma, S., Verma, A., Saxena, G., 2012. A comparative study on the toxicity of a synthetic pesticide, dichlorvos and a neem based pesticide, neemon to Labeo rohita (Hamilton). Curr. World Environ. 7, 157-161.
Bilia, A.R., Guccione, C., Isacchi, B., Righeschi, C., Firenzuoli, F., Bergonzi, M.C., 2014. Essential oils loaded in nanosystems: a developing strategy for a successful therapeutic approach. Evid. Based Complement. Alternat. Med. 2014, 1-14. http://dx. doi.org/10.1155/2014/651593.

Bissinger, B.W., Roe, R.M., 2010. Tick repellents: past, present, and future. Pestic. Biochem. Physiol. 96, 63-79. http://dx.doi.org/10.1016/j.pestbp.2009.09.010.

Blázquez, M., 2014. Role of natural essential oils in sustainable agriculture and food preservation. J. Sci. Res. Rep. 3, 1843-1860. http://dx.doi.org/10.9734/JSRR/2014/ 11376.

Bravo, A., Martínez de Castro, D.L., Sánchez, J., Cantón, P.E., Mendoza, G., Gómez, I. Pacheco, S., García-Gómez, B.I., Onofre, J., Ocelotl, J., Soberón, M., 2015. 30 Mechanism of action of Bacillus thuringiensis insecticidal toxins and their use in the control of insect pests. In: Alouf, J., Ladant, D., Popoff, M.R. (Eds.), The Comprehensive Sourcebook of Bacterial Protein Toxins, fourth ed. Academic Press, Boston, pp. 858-873. http://dx.doi.org/10.1016/B978-0-12-800188-2.00030-6.

Burt, S., 2004. Essential oils: their antibacterial properties and potential applications in foods? A review. Int. J. Food Microbiol. 94, 223-253. http://dx.doi.org/10.1016/j. ijfoodmicro.2004.03.022.

Caira, S., Ferranti, P., 2016. Innovation for sustainable agriculture and food production. In: Reference Module in Food Science. Elsevier. http://dx.doi.org/10.1016/B978-008-100596-5.21018-4.

Campos, E.V.R., de Oliveira, J.L., Fraceto, L.F., 2014. Applications of controlled release systems for fungicides, herbicides, acaricides, nutrients, and plant growth hormones: a review. Adv. Sci. Eng. Med. 6, 373-387. http://dx.doi.org/10.1166/asem.2014. 1538.

Campos, E.V.R., de Oliveira, J.L., Fraceto, L.F., Singh, B., 2015. Polysaccharides as safer release systems for agrochemicals. Agron. Sustainable Dev. 35, 47-66. http://dx.doi. org/10.1007/s13593-014-0263-0.

Campos, E.V.R., de Oliveira, J.L., Pascoli, M., de Lima, R., Fraceto, L.F., 2016. Neem oil and crop protection: from now to the future. Front. Plant Sci. 7. http://dx.doi.org/10 3389/fpls.2016.01494.

Carrubba, A., Catalano, C., 2009. Essential oil crops for sustainable agriculture - a review. In: Lichtfouse, E. (Ed.), Climate Change, Intercropping, Pest Control and Beneficial Microorganisms. Springer, Netherlands, Dordrecht, pp. 137-187. http://dx.doi.org/ 10.1007/978-90-481-2716-0_8.

Chandler, D., Bailey, A.S., Tatchell, G.M., Davidson, G., Greaves, J., Grant, W.P., 2011. The development, regulation and use of biopesticides for integrated pest management. Philos. Trans. R. Soc. B: Biol. Sci. 366, 1987-1998. http://dx.doi.org/10.1098/ rstb. 2010.0390 .

Chaplain, V., Mamy, L., Vieublé-Gonod, L., Mougin, C., Benoit, P., Barriuso, E., Nélieu, S., 2011. Fate of pesticides in soils: toward an integrated approach of influential factors. Pesticides in the Modern World-Risks and Benefits. InTech.

Chaudhary, S., Misra, S., 2017. Nanotechnology: resource management for sustainable agriculture. Indian Res. J. Genet. Biotechnol. 9, 310-313.

Chen, F., Shi, Z., Neoh, K.G., Kang, E.T., 2009. Antioxidant and antibacterial activities of eugenol and carvacrol-grafted chitosan nanoparticles. Biotechnol. Bioeng. 104, 30-39. http://dx.doi.org/10.1002/bit.22363.

Chen, H., Yada, R., 2011. Nanotechnologies in agriculture: new tools for sustainable development. Trends Food Sci. Technol. 22, 585-594. http://dx.doi.org/10.1016/j. tifs.2011.09.004.

Chen, H., Zhang, Y., Zhong, Q., 2015. Physical and antimicrobial properties of spray-dried zein-casein nanocapsules with co-encapsulated eugenol and thymol. J. Food Eng. 144, 93-102. http://dx.doi.org/10.1016/j.jfoodeng.2014.07.021.

Chhipa, H., 2017. Nanopesticide: current status and future possibilities. Agric. Res. Technol. Open Access J. 5. http://dx.doi.org/10.19080/ARTOAJ.2017.05.555651.

Chowdhury, A., Pradhan, S., Saha, M., Sanyal, N., 2008. Impact of pesticides on soil microbiological parameters and possible bioremediation strategies. Indian J. Microbiol. 48, 114-127. http://dx.doi.org/10.1007/s12088-008-0011-8.

Chowdhury, A., Odame, H.H., Thompson, S., Hauser, M., 2015. Enhancing farmers' capacity for botanical pesticide innovation through video-mediated learning in Bangladesh. Int. J. Agric. Sustainable 13, 326-349. http://dx.doi.org/10.1080/ 14735903.2014.997461.

Conti, B., Flamini, G., Cioni, P.L., Ceccarini, L., Macchia, M., Benelli, G., 2014. Mosquitocidal essential oils: are they safe against non-target aquatic organisms? Parasitol. Res. 113, 251-259. http://dx.doi.org/10.1007/s00436-013-3651-5.

Copping, L.G., Duke, S.O., 2007. Natural products that have been used commercially as crop protection agents. Pest Manage. Sci. 63, 524-554. http://dx.doi.org/10.1002/ ps.1378.

Cretoiu, M.S., Korthals, G.W., Visser, J.H.M., van Elsas, J.D., 2013. Chitin amendment increases soil suppressiveness toward plant pathogens and modulates the actinobacterial and oxalobacteraceal communities in an experimental agricultural field. Appl. Environ. Microbiol. 79, 5291-5301. http://dx.doi.org/10.1128/AEM. 01361-13.

Cycon, M., Mrozik, A., Piotrowska-Seget, Z., 2017. Bioaugmentation as a strategy for the remediation of pesticide-polluted soil: a review. Chemosphere 172, 52-71. http://dx. doi.org/10.1016/j.chemosphere.2016.12.129.

Dabrowski, J.M., Shadung, J.M., Wepener, V., 2014. Prioritizing agricultural pesticides used in South Africa based on their environmental mobility and potential human health effects. Environ. Int. 62, 31-40. http://dx.doi.org/10.1016/j.envint.2013.10. 001

Damin, V., Trivelin, P., 2011. Herbicides effect on nitrogen cycling in agroecosystems. Herbicides and Environment. InTech.

Dar, S.A., Dar, N.A., Bhat, M.A., Bhat, M.H., 2014. Prospects, utilization and challenges of botanical pesticides in sustainable agriculture. Int. J. Mol. Biol. Biochem. 2, 1-14.

Daviet, L., Schalk, M., 2010. Biotechnology in plant essential oil production: progress and perspective in metabolic engineering of the terpene pathway. Flavour Fragr. J. 25, 
123-127. http://dx.doi.org/10.1002/ffj.1981.

Dayan, F.E., Cantrell, C.L., Duke, S.O., 2009. Natural products in crop protection. Bioorg. Med. Chem. 17, 4022-4034. http://dx.doi.org/10.1016/j.bmc.2009.01.046.

de la Guardia, M., 2014. The challenges of green nanotechnology. BioImpacts BI 4, 1-2. http://dx.doi.org/10.5681/bi.2014.009.

de Oliveira, J.L., Campos, E.V.R., Bakshi, M., Abhilash, P.C., Fraceto, L.F., 2014 Application of nanotechnology for the encapsulation of botanical insecticides for sustainable agriculture: prospects and promises. Biotechnol. Adv. 32, 1550-1561. http://dx.doi.org/10.1016/j.biotechadv.2014.10.010.

Demont, M., Mathijs, E., Tollens, E., 2001. Impact of new technologies on agricultural production systems: the cases of agricultural biotechnology and automatic milking. New Technol. Sustainable Bruss. CLE-CEA 11-38.

Devi, K.P., Nisha, S.A., Sakthivel, R., Pandian, S.K., 2010. Eugenol (an essential oil of clove) acts as an antibacterial agent against Salmonella typhi by disrupting the cellular membrane. J. Ethnopharmacol. 130, 107-115. http://dx.doi.org/10.1016/j.jep 2010.04.025.

Dickens, J.C., Bohbot, J.D., 2013. Mini review: mode of action of mosquito repellents. Pestic. Biochem. Physiol. 106, 149-155. http://dx.doi.org/10.1016/j.pestbp.2013. 02.006.

Donatelli, M., Magarey, R.D., Bregaglio, S., Willocquet, L., Whish, J.P.M., Savary, S. 2017. Modelling the impacts of pests and diseases on agricultural systems. Agric. Syst. http://dx.doi.org/10.1016/j.agsy.2017.01.019.

Donsì, F., Cuomo, A., Marchese, E., Ferrari, G., 2014. Infusion of essential oils for food stabilization: unraveling the role of nanoemulsion-based delivery systems on mass transfer and antimicrobial activity. Innov. Food Sci. Emerg. Technol. 22, 212-220. http://dx.doi.org/10.1016/j.ifset.2014.01.008.

dos Santos, N., Gottschalk Nolasco, L., 2017. A ênfase sobre conduta ética e os fatores incerteza e a condição humana inerentes às nanotecnologias - DOI: 10.12818/ P.0304-2340.2016v69p441. Rev. Fac. Direito UFMG. http://dx.doi.org/10.12818/P 0304-2340.2016v69p441.

Duah-Yentumi, S., Johnson, D.B., 1986. Changes in soil microflora in response to repeated applications of some pesticides. Soil Biol. Biochem. 18, 629-635. http://dx.doi.org/ 10.1016/0038-0717(86)90086-6.

Dubey, N.K., Shukla, R., Kumar, A., Singh, P., Prakash, B., 2010. Prospects of botanical pesticides in sustainable agriculture. Curr. Sci. 98, 479-480.

Duhan, J.S., Kumar, R., Kumar, N., Kaur, P., Nehra, K., Duhan, S., 2017. Nanotechnology: the new perspective in precision agriculture. Biotechnol. Rep. 15, 11-23. http://dx. doi.org/10.1016/j.btre.2017.03.002.

Ebadollahi, A., Sendi, J.J., Aliakbar, A., 2017. Efficacy of nanoencapsulated Thymus eriocalyx and Thymus kotschyanus essential oils by a mesoporous material MCM-41 against Tetranychus urticae (Acari: Tetranychidae). J. Econ. Entomol. 110, 2413-2420. http://dx.doi.org/10.1093/jee/tox234.

El-Wakeil, N.E., 2013. Botanical pesticides and their mode of action. Gesunde Pflanz. 65, 125-149. http://dx.doi.org/10.1007/s10343-013-0308-3.

Enan, E., 2001. Insecticidal activity of essential oils: octopaminergic sites of action. Comp. Biochem. Physiol. Toxicol. Pharmacol. 130, 325-337.

Enan, E.E., 2005a. Molecular response of Drosophila melanogaster tyramine receptor cascade to plant essential oils. Insect Biochem. Mol. Biol. 35, 309-321. http://dx.doi. org/10.1016/j.ibmb.2004.12.007.

Enan, E.E., 2005b. Molecular and pharmacological analysis of an octopamine receptor from American cockroach and fruit fly in response to plant essential oils. Arch. Insect Biochem. Physiol. 59, 161-171. http://dx.doi.org/10.1002/arch.20076.

Engel, J.B., Heckler, C., Tondo, E.C., Daroit, D.J., da Silva Malheiros, P., 2017. Antimicrobial activity of free and liposome-encapsulated thymol and carvacrol against Salmonella and Staphylococcus aureus adhered to stainless steel. Int. J. Food Microbiol. 252, 18-23. http://dx.doi.org/10.1016/j.ijfoodmicro.2017.04.003.

European, C., 2012. EC, Communication from the Commission to the European Parliament, the Council, the European Economic and Social Committee and the Committee of the Regions. 'A European Strategy for Key Enabling Technologies - A Bridge to Growth and Jobs'. http://eur-europa.eu/LexUriServ/LexUriServ.do?uri= COM.

Evenson, R.E., 2003. Assessing the impact of the Green Revolution, 1960 to 2000. Science 300, 758-762. http://dx.doi.org/10.1126/science.1078710.

Ezhil Vendan, S., 2016. Current scenario of biopesticides and eco-friendly insect pest management in India. South Indian J. Biol. Sci. 2, 268. https://doi.org/10.22205/ sijbs/2016/v2/i2/100315.

Fischer, D., Imholt, C., Pelz, H.-J., Wink, M., Prokop, A., Jacob, J., 2013. The repelling effect of plant secondary metabolites on water voles, Arvicola amphibius. Pest Manage. Sci. 69, 437-443. http://dx.doi.org/10.1002/ps.3438.

Fountain, E.D., Wratten, S.D., 2013. Conservation biological control and biopesticides in agricultural. In: Reference Module in Earth Systems and Environmental Sciences. Elsevier. http://dx.doi.org/10.1016/B978-0-12-409548-9.00539-X.

Fraceto, L.F., Grillo, R., Medeiros, D.A.G., Scognamiglio, V., Rea, G., Bartolucci, C., 2016. Nanotechnology in agriculture: which innovation potential does it have? Front. Environ. Sci. 4. http://dx.doi.org/10.3389/fenvs.2016.00020.

Gabriel Paulraj, M., Ignacimuthu, S., Gandhi, M.R., Shajahan, A., Ganesan, P., Packiam, S.M., Al-Dhabi, N.A., 2017. Comparative studies of tripolyphosphate and glutaraldehyde cross-linked chitosan-botanical pesticide nanoparticles and their agricultural applications. Int. J. Biol. Macromol. http://dx.doi.org/10.1016/j.ijbiomac. 2017.06.043.

García, D.A., Bujons, J., Vale, C., Suñol, C., 2006. Allosteric positive interaction of thymol with the GABAA receptor in primary cultures of mouse cortical neurons. Neuropharmacology 50, 25-35. http://dx.doi.org/10.1016/j.neuropharm.2005.07. 009.

George, D.R., Sparagano, O.A.E., Port, G., Okello, E., Shiel, R.S., Guy, J.H., 2010. Toxicity of plant essential oils to different life stages of the poultry red mite, Dermanyssus gallinae, and non-target invertebrates. Med. Vet. Entomol. 24, 9-15. http://dx.doi. org/10.1111/j.1365-2915.2009.00856.x.

Gerland, P., Raftery, A.E., Ševcíková, H., Li, N., Gu, D., Spoorenberg, T., Alkema, L., Fosdick, B.K., Chunn, J., Lalic, N., Bay, G., Buettner, T., Heilig, G.K., Wilmoth, J. 2014. World population stabilization unlikely this century. Science 346, 234-237. http://dx.doi.org/10.1126/science.1257469.

Gevao, B., Semple, K.T., Jones, K.C., 2000. Bound pesticide residues in soils: a review. Environ. Pollut. 108, 3-14. http://dx.doi.org/10.1016/S0269-7491(99)00197-9.

Grassini, P., Eskridge, K.M., Cassman, K.G., 2013. Distinguishing between yield advances and yield plateaus in historical crop production trends. Nat. Commun. 4 ncomms3918. http://dx.doi.org/10.1038/ncomms3918.

Grumezescu, A.M., 2017. New Pesticides and Soil Sensors. Academic Press.

Guimarães, A.G., Oliveira, M.A., Alves, R. dos S., Menezes, P. dos P., Serafini, M.R., de Souza Araújo, A.A., Bezerra, D.P., Quintans Júnior, L.J., 2015. Encapsulation of carvacrol, a monoterpene present in the essential oil of oregano, with $\beta$-cyclodextrin, improves the pharmacological response on cancer pain experimental protocols. Chem. Biol. Interact. 227, 69-76. http://dx.doi.org/10.1016/j.cbi.2014.12.020.

Hall, A.C., Turcotte, C.M., Betts, B.A., Yeung, W.-Y., Agyeman, A.S., Burk, L.A., 2004 Modulation of human GABAA and glycine receptor currents by menthol and related monoterpenoids. Eur. J. Pharmacol. 506, 9-16. http://dx.doi.org/10.1016/j.ejphar. 2004.10.026.

Hartmann, M., Frey, B., Mayer, J., Mäder, P., Widmer, F., 2015. Distinct soil microbial diversity under long-term organic and conventional farming. ISME J. 9, 1177-1194. http://dx.doi.org/10.1038/ismej.2014.210.

Herman, A., Tambor, K., Herman, A., 2016. Linalool affects the antimicrobial efficacy of essential oils. Curr. Microbiol. 72, 165-172. http://dx.doi.org/10.1007/s00284-0150933-4.

Hernández-Moreno, D., Soffers, A.E.M.F., WiratnoFalke, H.E., Rietjens, I.M.C.M., Murk, A.J., 2013. Consumer and farmer safety evaluation of application of botanical pesticides in black pepper crop protection. Food Chem. Toxicol. 56, 483-490. http://dx. doi.org/10.1016/j.fct.2013.01.033.

Hess, P.N., 2016. Economic Growth and Sustainable Development. Routledge.

Höld, K.M., Sirisoma, N.S., Ikeda, T., Narahashi, T., Casida, J.E., 2000. Alpha-thujone (the active component of absinthe): gamma-aminobutyric acid type A receptor modulation and metabolic detoxification. Proc. Natl. Acad. Sci. U.S.A. 97, 3826-3831. http://dx.doi.org/10.1073/pnas.070042397.

Hsu, C.-C., Lai, W.-L., Chuang, K.-C., Lee, M.-H., Tsai, Y.-C., 2013. The inhibitory activity of linalool against the filamentous growth and biofilm formation in Candida albicans. Med. Mycol. 51, 473-482. http://dx.doi.org/10.3109/13693786.2012.743051.

Hussain, T., 2017. Nanocides: smart delivery system in agriculture and horticultural crops. Adv. Plants Agric. Res. 6. http://dx.doi.org/10.15406/apar.2017.06.00233.

Iavicoli, I., Leso, V., Beezhold, D.H., Shvedova, A.A., 2017. Nanotechnology in agriculture: opportunities, toxicological implications, and occupational risks. Toxicol. Appl. Pharmacol. 329, 96-111. http://dx.doi.org/10.1016/j.taap.2017.05.025.

Isman, M.B., 2000a. Plant essential oils for pest and disease management. In: Crop Prot XIVth International Plant Protection Congress, vol. 19, pp. 603-608. http://dx.doi. org/10.1016/S0261-2194(00)00079-X.

Isman, M.B., 2000b. Plant essential oils for pest and disease management. Crop Prot. 19, 603-608. http://dx.doi.org/10.1016/S0261-2194(00)00079-X.

Isman, M.B., 2006. Botanical insecticides, deterrents, and repellents in modern agriculture and an increasingly regulated world. Annu. Rev. Entomol. 51, 45-66. http:// dx.doi.org/10.1146/annurev.ento.51.110104.151146.

Isman, M.B., Grieneisen, M.L., 2014. Botanical insecticide research: many publications, limited useful data. Trends Plant Sci. 19, 140-145. http://dx.doi.org/10.1016/j. tplants.2013.11.005.

Isman, M.B., Paluch, G., 2011. Chapter 7. Needles in the haystack: exploring chemical diversity of botanical insecticides. In: Lòpez, Òscar, Fernàndez-Bolaños, J.G. (Eds.), RSC Green Chemistry. Royal Society of Chemistry, Cambridge, pp. 248-265. http:// dx.doi.org/10.1039/9781849732901-00248.

Isman, M.B., Miresmailli, S., Machial, C., 2011. Commercial opportunities for pesticides based on plant essential oils in agriculture, industry and consumer products. Phytochem. Rev. 10, 197-204. http://dx.doi.org/10.1007/s11101-010-9170-4.

Jain, A., Ranjan, S., Dasgupta, N., Ramalingam, C., 2016. Nanomaterials in food and agriculture: an overview on their safety concerns and regulatory issues. Crit. Rev. Food Sci. Nutr. 1-21. http://dx.doi.org/10.1080/10408398.2016.1160363.

Kadoglidou, K., Lagopodi, A., Karamanoli, K., Vokou, D., Bardas, G.A., Menexes, G. Constantinidou, H.-I.A., 2011. Inhibitory and stimulatory effects of essential oils and individual monoterpenoids on growth and sporulation of four soil-borne fungal isolates of Aspergillus terreus, Fusarium oxysporum, Penicillium expansum, and Verticillium dahliae. Eur. J. Plant Pathol. 130, 297-309. http://dx.doi.org/10.1007/ s10658-011-9754-x.

Kah, M., Hofmann, T., 2014. Nanopesticide research: current trends and future priorities Environ. Int. 63, 224-235. http://dx.doi.org/10.1016/j.envint.2013.11.015.

Kamari, A., Pulford, I.D., Hargreaves, J.S.J., 2011. Chitosan as a potential amendment to remediate metal contaminated soil - a characterisation study. Colloids Surf. B: Biointerfaces 82, 71-80. http://dx.doi.org/10.1016/j.colsurfb.2010.08.019.

Karani, A., Ndakidemi, P., Mbega, E., 2017. Botanical pesticides in management of common bean pests: importance and possibilities for adoption by small-scale farmers in Africa. J. Appl. Life Sci. Int. 12, 1-10. http://dx.doi.org/10.9734/JALSI/2017/ 32503.

Katiyar, D., Hemantaranjan, A., Singh, B., Bhanu, A.N., 2014. A Future perspective in crop protection: chitosan and its oligosaccharides. Adv. Plants Agric. Res. 1, 1-8. https:// doi.org/10.15406/apar.2014.1.00006.

Kaur, H., Garg, H., 2014. Pesticides: environmental impacts and management strategies. In: Soloneski, S. (Ed.), Pesticides - Toxic Aspects. InTech. http://dx.doi.org/10.5772/ 57399. 
Keawchaoon, L., Yoksan, R., 2011. Preparation, characterization and in vitro release study of carvacrol-loaded chitosan nanoparticles. Colloids Surf. B: Biointerfaces 84, 163-171. http://dx.doi.org/10.1016/j.colsurfb.2010.12.031.

Khaliq, A., Khan, A.A., Afzal, M., Tahir, H.M., Raza, A.M., Khan, A.M., 2014. Field evaluation of selected botanicals and commercial synthetic insecticides against Thrips tabaci Lindeman (Thysanoptera: Thripidae) populations and predators in onion field plots. Crop Prot. 62, 10-15. http://dx.doi.org/10.1016/j.cropro.2014.03.019.

Khani, A., Asghari, J., 2012. Insecticide activity of essential oils of Mentha longifolia, Pulicaria gnaphalodes and Achillea wilhelmsii against two stored product pests, the flour beetle, Tribolium castaneum, and the cowpea weevil, Callosobruchus maculatus. J. Insect Sci. 12. http://dx.doi.org/10.1673/031.012.7301.

Khani, A., Rahdari, T., 2012. Chemical composition and insecticidal activity of essential oil from Coriandrum sativum seeds against Tribolium confusum and Callosobruchus maculatus. ISRN Pharm. 2012. http://dx.doi.org/10.5402/2012/263517.

Khoobdel, M., Ahsaei, S.M., Farzaneh, M., 2017. Insecticidal activity of polycaprolactone nanocapsules loaded with Rosmarinus officinalis essential oil in Tribolium castaneum (Herbst). Entomol. Res. 47, 175-184. http://dx.doi.org/10.1111/1748-5967.12212.

Kibblewhite, M., Ritz, K., Swift, M., 2008. Soil health in agricultural systems. Philos. Trans. R. Soc. B: Biol. Sci. 363, 685-701. http://dx.doi.org/10.1098/rstb.2007.2178.

Kniss, A.R., 2017. Long-term trends in the intensity and relative toxicity of herbicide use. Nat. Commun. 8, 14865. http://dx.doi.org/10.1038/ncomms14865.

Komorowicz, I., Gramowska, H., Barałkiewicz, D., 2010. Estimation of the lake water pollution by determination of 18 elements using ICP-MS method and their statistical analysis. J. Environ. Sci. Health Part A 45, 348-354. http://dx.doi.org/10.1080/ 10934520903467873.

Kookana, R.S., Baskaran, S., Naidu, R., 1998. Pesticide fate and behaviour in Australian soils in relation to contamination and management of soil and water: a review. Aust. J. Soil Res. 36, 715. http://dx.doi.org/10.1071/S97109.

Koul, O., Singh, R., Kaur, B., Kanda, D., 2013. Comparative study on the behavioral response and acute toxicity of some essential oil compounds and their binary mixtures to larvae of Helicoverpa armigera, Spodoptera litura and Chilo partellus. Ind. Crops Prod. 49, 428-436. http://dx.doi.org/10.1016/j.indcrop.2013.05.032.

Krasowski, M.D., Hong, X., Hopfinger, A.J., Harrison, N.L., 2002. 4D-QSAR analysis of a set of propofol analogues: mapping binding sites for an anesthetic phenol on the GABAA receptor. J. Med. Chem. 45, 3210-3221.

Kumar, S., 2012. Biopesticides: a need for food and environmental safety. J. Biofertil. Biopestic. 03. http://dx.doi.org/10.4172/2155-6202.1000e107.

Kumar, S., 2013. The role of biopesticides in sustainably feeding the nine billion global populations. J. Biofertil. Biopestic. 04. http://dx.doi.org/10.4172/2155-6202. $1000 \mathrm{e} 114$.

Kumar, M., Shamsi, T.N., Parveen, R., Fatima, S., 2017. Application of nanotechnology in enhancement of crop productivity and integrated pest management. In: Prasad, R., Kumar, M., Kumar, V. (Eds.), Nanotechnology. Springer Singapore, Singapore, pp. 361-371. http://dx.doi.org/10.1007/978-981-10-4573-8 17.

Kumbhar, P., Dewang, P.M., 2001. Monoterpenoids: thenatural pest management agents. Fragrance Flavor Assoc. India 3, 49-56.

Kumrungsee, N., Pluempanupat, W., Koul, O., Bullangpoti, V., 2014. Toxicity of essential oil compounds against diamondback moth, Plutella xylostella, and their impact on detoxification enzyme activities. J. Pest Sci. 87, 721-729. http://dx.doi.org/10. 1007/s10340-014-0602-6.

Lambert, R.J., Skandamis, P.N., Coote, P.J., Nychas, G.J., 2001. A study of the minimum inhibitory concentration and mode of action of oregano essential oil, thymol and carvacrol. J. Appl. Microbiol. 91, 453-462.

Lechenet, M., Bretagnolle, V., Bockstaller, C., Boissinot, F., Petit, M.-S., Petit, S., MunierJolain, N.M., 2014. Reconciling pesticide reduction with economic and environmental sustainability in arable farming. PLoS One 9, e97922. http://dx.doi.org/10. 1371/journal.pone.0097922.

Lee, S., Peterson, C.J., Coats, J.R., 2003. Fumigation toxicity of monoterpenoids to several stored product insects. J. Stored Prod. Res. 39, 77-85.

Lu, Y., Ozcan, S., 2015. Green nanomaterials: on track for a sustainable future. Nano Today 10, 417-420. http://dx.doi.org/10.1016/j.nantod.2015.04.010.

Malik, Z., Ahmad, M., Abassi, G.H., Dawood, M., Hussain, A., Jamil, M., 2017. Agrochemicals and soil microbes: interaction for soil health. In: Hashmi, M.Z., Kumar, V., Varma, A. (Eds.), Xenobiotics in the Soil Environment, Soil Biology. Springer International Publishing, pp. 139-152. http://dx.doi.org/10.1007/978-3319-47744-2_11.

Marchand, P.A., 2015. Basic substances: an opportunity for approval of low-concern substances under EU pesticide regulation. Pest Manage. Sci. 71, 1197-1200. http:// dx.doi.org/10.1002/ps.3997.

Marques, H.M.C., 2010. A review on cyclodextrin encapsulation of essential oils and volatiles. Flavour Fragrance J. 25, 313-326. http://dx.doi.org/10.1002/ffj.2019.

Martin-Guay, M.-O., Paquette, A., Dupras, J., Rivest, D., 2018. The new green revolution: sustainable intensification of agriculture by intercropping. Sci. Total Environ. 615, 767-772. http://dx.doi.org/10.1016/j.scitotenv.2017.10.024.

Mattos, B.D., Tardy, B.L., Magalhães, W.L.E., Rojas, O.J., 2017. Controlled release for crop and wood protection: recent progress toward sustainable and safe nanostructured biocidal systems. J. Controll. Release 262, 139-150. http://dx.doi.org/10. 1016/j.jconrel.2017.07.025.

Maynard, A.D., 2014. A decade of uncertainty. Nat. Nanotechnol. 9, 159-160. http://dx. doi.org/10.1038/nnano.2014.43.

Meite, F., Alvarez-Zaldívar, P., Crochet, A., Wiegert, C., Payraudeau, S., Imfeld, G., 2018. Impact of rainfall patterns and frequency on the export of pesticides and heavymetals from agricultural soils. Sci. Total Environ. 616-617, 500-509. http://dx.doi. org/10.1016/j.scitotenv.2017.10.297.

Mishra, S., Keswani, C., Abhilash, P.C., Fraceto, L.F., Singh, H.B., 2017. Integrated approach of agri-nanotechnology: challenges and future trends. Front. Plant Sci. 8. http://dx.doi.org/10.3389/fpls.2017.00471.

Mossa, A.-T.H., 2016. Green pesticides: essential oils as biopesticides in insect-pest management. J. Environ. Sci. Technol. 9, 354-378. http://dx.doi.org/10.3923/jest. 2016.354.378.

Mukhopadhyay, S.S., 2014. Nanotechnology in agriculture: prospects and constraints. Nanotechnol. Sci. Appl. 7, 63-71. http://dx.doi.org/10.2147/NSA.S39409.

Müller, G.C., Junnila, A., Butler, J., Kravchenko, V.D., Revay, E.E., Weiss, R.W., Schlein, Y., 2009. Efficacy of the botanical repellents geraniol, linalool, and citronella against mosquitoes. J. Vector Ecol. J. Soc. Vector Ecol. 34, 2-8. http://dx.doi.org/10.1111/j. 1948-7134.2009.00002.x

Nagegowda, D.A., 2010. Plant volatile terpenoid metabolism: biosynthetic genes, transcriptional regulation and subcellular compartmentation. FEBS Lett. 584, 2965-2973. http://dx.doi.org/10.1016/j.febslet.2010.05.045.

Nair, R., Varghese, S.H., Nair, B.G., Maekawa, T., Yoshida, Y., Kumar, D.S., 2010. Nanoparticulate material delivery to plants. Plant Sci. 179, 154-163. http://dx.doi. org/10.1016/j.plantsci.2010.04.012.

Narva, K.E., Storer, N.P., Meade, T., 2014. Discovery and Development of insect-resistant crops using genes from Bacillus thuringiensis. In: Advances in Insect Physiology. Elsevier, pp. 177-247. http://dx.doi.org/10.1016/B978-0-12-800197-4.00004-X.

Nath, D., Banerjee, P., 2013. Green nanotechnology? A new hope for medical biology. Environ. Toxicol. Pharmacol. 36, 997-1014. http://dx.doi.org/10.1016/j.etap.2013. 09.002 .

Ndakidemi, B., Mtei, K., Ndakidemi, P.A., 2016. Impacts of synthetic and botanical pesticides on beneficial insects. Agric. Sci. 07, 364-372. http://dx.doi.org/10.4236/as. 2016.76038 .

Negahban, M., Moharramipour, S., Zandi, M., Hashemi, S.A., Ziayee, F., 2012. Nanoinsecticidal activity of essential oil from Cuminum cyminum on Tribolium castaneum. In: Proc 9th. Int. Conf. on Controlled Atmosphere and Fumigation in Stored Products, Antalya, Turkey. pp. 63-68.

Negahban, M., Moharramipour, S., Sefidkon, F., 2007. Fumigant toxicity of essential oil from Artemisia sieberi Besser against three stored-product insects. J. Stored Prod. Res. 43, 123-128. http://dx.doi.org/10.1016/j.jspr.2006.02.002.

Negahban, M., Moharramipour, S., Zand, M., Hashemi, S., 2014. Repellent activity of nanoencapsulated essential oil of Artemisia sieberi besser on Plutella xylostella L. LARVAE 29, 909-924.

Nerio, L.S., Olivero-Verbel, J., Stashenko, E., 2010. Repellent activity of essential oils: a review. Bioresour. Technol. 101, 372-378. http://dx.doi.org/10.1016/j.biortech. 2009.07 .048$.

Niu, Y., Qureshi, J.A., Ni, X., Head, G.P., Price, P.A., Meagher, R.L., Kerns, D., Levy, R., Yang, X., Huang, F., 2016. F2 screen for resistance to Bacillus thuringiensis Cry2Ab2maize in field populations of Spodoptera frugiperda (Lepidoptera: Noctuidae) from the southern United States. J. Invertebr. Pathol. 138, 66-72. http://dx.doi.org/10 1016/j.jip.2016.06.005

Oliveira, A.P., Santana, A.S., Santana, E.D.R., Lima, A.P.S., Faro, R.R.N., Nunes, R.S., Lima, A.D., Blank, A.F., Araújo, A.P.A., Cristaldo, P.F., Bacci, L., 2017. Nanoformulation prototype of the essential oil of Lippia sidoides and thymol to population management of Sitophilus zeamais (Coleoptera: Curculionidae). Ind. Crops Prod. 107, 198-205. http://dx doi.org/10.1016/j.indcrop.2017.05.046.

Papatheodorou, E.M., Margariti, C., Vokou, D., 2014. Effects of the two carvone enantiomers on soil enzymes involved in the C, P, and N cycles. J. Biol. Res. 21. http:// dx.doi.org/10.1186/2241-5793-21-7.

Park, Y.-L., Tak, J.-H., 2016. Essential oils for arthropod pest management in agricultural production systems. In: Essential Oils in Food Preservation, Flavor and Safety. Elsevier, pp. 61-70. http://dx.doi.org/10.1016/B978-0-12-416641-7.00006-7.

Parsa, S., Morse, S., Bonifacio, A., Chancellor, T.C.B., Condori, B., Crespo-Pérez, V., Hobbs, S.L.A., Kroschel, J., Ba, M.N., Rebaudo, F., Sherwood, S.G., Vanek, S.J., Faye, E., Herrera, M.A., Dangles, O., 2014. Obstacles to integrated pest management adoption in developing countries. Proc. Natl. Acad. Sci. U.S.A. 111, 3889-3894. http://dx.doi.org/10.1073/pnas.1312693111.

Pascual-Villalobos, M., Robledo, A., 1998. Screening for anti-insect activity in Mediterranean plants. Ind. Crops Prod. 8, 183-194. http://dx.doi.org/10.1016/ S0926-6690(98)00002-8.

Pavela, R., 2011. Antifeedant and larvicidal effects of some phenolic components of essential oils lasp lines of introduction against Spodoptera littoralis (Boisd.). J. Essent. Oil Bear. Plants 14, 266-273. http://dx.doi.org/10.1080/0972060X.2011.10643932.

Pavela, R., 2014. Limitation of plant biopesticides. In: Singh, D. (Ed.), Advances in Plant Biopesticides. Springer, India, pp. 347-359. http://dx.doi.org/10.1007/978-81-3222006-0_17.

Pavela, R., Benelli, G., 2016. Essential oils as ecofriendly biopesticides? Challenges and constraints. Trends Plant Sci. 21, 1000-1007. http://dx.doi.org/10.1016/j.tplants. 2016.10.005

Peana, A.T., De Montis, M.G., Nieddu, E., Spano, M.T., D’Aquila, P.S., Pippia, P., 2004a Profile of spinal and supra-spinal antinociception of ( - -)-linalool. Eur. J. Pharmacol. 485, 165-174.

Peana, A.T., De Montis, M.G., Sechi, S., Sircana, G., D’Aquila, P.S., Pippia, P., 2004b. Effects of (-)-linalool in the acute hyperalgesia induced by carrageenan, L-glutamate and prostaglandin E2. Eur. J. Pharmacol. 497, 279-284. http://dx.doi.org/10.1016/ j.ejphar.2004.06.006.

Perry, E.D., Ciliberto, F., Hennessy, D.A., Moschini, G., 2016. Genetically engineered crops and pesticide use in U.S. maize and soybeans. Sci. Adv. 2, e1600850. http://dx. doi.org/10.1126/sciadv.1600850.

Perry, N.S.L., Houghton, P.J., Theobald, A., Jenner, P., Perry, E.K., 2000. In-vitro inhibition of human erythrocyte acetylcholinesterase by Salvia lavandulaefolia essential oil and constituent terpenes. J. Pharm. Pharmacol. 52, 895-902. http://dx.doi.org/ 10.1211/0022357001774598

Pimentel, D., Burgess, M., 2013. Soil erosion threatens food production. Agriculture 3, 
443-463. http://dx.doi.org/10.3390/agriculture3030443.

Pingali, P.L., 2012. Green revolution: impacts, limits, and the path ahead. Proc. Natl. Acad. Sci. U.S.A. 109, 12302-12308. http://dx.doi.org/10.1073/pnas.0912953109.

Pleissner, D., 2017. Green chemistry and the leisure industry: new business models for sustainability. Curr. Opin. Green Sustainable Chem. 8, 1-4. http://dx.doi.org/10. 1016/j.cogsc.2017.06.005.

Posocco, B., Dreussi, E., de Santa, J., Toffoli, G., Abrami, M., Musiani, F., Grassi, M., Farra, R., Tonon, F., Grassi, G., Dapas, B., 2015. Polysaccharides for the delivery of antitumor drugs. Materials 8, 2569-2615. http://dx.doi.org/10.3390/ma8052569.

Prasad, R., Bhattacharyya, A., Nguyen, Q.D., 2017. Nanotechnology in sustainable agri culture: recent developments, challenges, and perspectives. Front. Microbiol. 8, 1014. http://dx.doi.org/10.3389/fmicb.2017.01014.

Pretty, J., Pervez Bharucha, Z., 2015. Integrated pest management for sustainable intensification of agriculture in Asia and Africa. Insects 6, 152-182. http://dx.doi.org/ 10.3390/insects6010152.

Price, D.N., Berry, M.S., 2006. Comparison of effects of octopamine and insecticidal essential oils on activity in the nerve cord, foregut, and dorsal unpaired median neurons of cockroaches. J. Insect Physiol. 52, 309-319. http://dx.doi.org/10.1016/j.jinsphys. 2005.11.010.

Priestley, C.M., Williamson, E.M., Wafford, K.A., Sattelle, D.B., 2003. Thymol, a constituent of thyme essential oil, is a positive allosteric modulator of human GABA receptors and a homo-oligomeric GABA receptor from Drosophila melanogaster. Br. J. Pharmacol. 140, 1363-1372. http://dx.doi.org/10.1038/sj.bjp.0705542.

Pyrrho, M., Schramm, F.R., 2012. The morality of nanotechnology. Cad. Saúde Pública 28, 2023-2033. http://dx.doi.org/10.1590/S0102-311X2012001100002.

Raemdonck, K., Martens, T.F., Braeckmans, K., Demeester, J., De Smedt, S.C., 2013. Polysaccharide-based nucleic acid nanoformulations. Adv. Drug Deliv. Rev. 65, 1123-1147. http://dx.doi.org/10.1016/j.addr.2013.05.002.

Rai, M., Ingle, A., 2012. Role of nanotechnology in agriculture with special reference to management of insect pests. Appl. Microbiol. Biotechnol. 94, 287-293. http://dx.doi. org/10.1007/s00253-012-3969-4.

Raja, N., 2013. Biopesticides and biofertilizers: ecofriendly sources for sustainable agriculture. J. Fertil. Pestic. 4. http://dx.doi.org/10.4172/2155-6202.1000e112.

Regnault-Roger, C., 1997. The potential of botanical essential oils for insect pest control. Integr. Pest Manage. Rev. 2, 25-34.

Regnault-Roger, C., Vincent, C., Arnason, J.T., 2012. Essential oils in insect control: lowrisk products in a high-stakes world. Annu. Rev. Entomol. 57, 405-424. http://dx. doi.org/10.1146/annurev-ento-120710-100554.

Retzbach, A., Maier, M., 2015. Communicating scientific uncertainty: media effects on public engagement with science. Commun. Res. 42, 429-456. http://dx.doi.org/10. $1177 / 0093650214534967$.

Riccardi, C. dos S., dos Santos, M.L., Guastaldi, A.C., 2015. Engineered nanomaterials, nanotoxicology issues, nanosafety and regulatory affairs, first ed. Cultura Acadêmica.

Rodríguez, J., Martín, M.J., Ruiz, M.A., Clares, B., 2016. Current encapsulation strategies for bioactive oils: from alimentary to pharmaceutical perspectives. Food Res. Int. 83, 41-59. http://dx.doi.org/10.1016/j.foodres.2016.01.032.

Ross, M.A., Lembi, C.A., 1985. Applied Weed Science. Burgess Publishing Co, Minneapolis, MN, USA.

Rousidou, C., Papadopoulou, E.S., Kortsinidou, M., Giannakou, I.O., Singh, B.K., Menkissoglu-Spiroudi, U., Karpouzas, D.G., 2013. Bio-pesticides: Harmful or harmless to ammonia oxidizing microorganisms? The case of a Paecilomyces lilacinusbased nematicide. Soil Biol. Biochem. 67, 98-105. http://dx.doi.org/10.1016/j. soilbio.2013.08.014.

Ryan, M.F., Byrne, O., 1988. Plant-insect coevolution and inhibition of acetylcholinesterase. J. Chem. Ecol. 14, 1965-1975. http://dx.doi.org/10.1007/ BF01013489.

Salamanca-Buentello, F., Persad, D.L., Court, E.B., Martin, D.K., Daar, A.S., Singer, P.A., 2005. Nanotechnology and the developing world. PLoS Med. 2, e97. http://dx.doi. org/10.1371/journal.pmed.0020097.

Salazar-Ledesma, M., Prado, B., Zamora, O., Siebe, C., 2018. Mobility of atrazine in soils of a wastewater irrigated maize field. Agric. Ecosyst. Environ. 255, 73-83. http://dx. doi.org/10.1016/j.agee.2017.12.018.

Saruchi, Kaith, B.S., Kumar, V., Jindal, R., 2016. Biodegradation study of enzymatically catalyzed interpenetrating polymer network: evaluation of agrochemical release and impact on soil fertility. Biotechnol. Rep. 9, 74-81. http://dx.doi.org/10.1016/j.btre. 2015.12.004.

Savini, V., Fazii, P., 2016. Chapter 12 - Bacillus thuringiensis insecticide properties. In: The Diverse Faces of Bacillus Cereus. Academic Press, pp. 139-155. http://dx.doi. org/10.1016/B978-0-12-801474-5.00012-8.

Scanes, C.G., 2018. Chapter 6 - the neolithic revolution, animal domestication, and early forms of animal agriculture. Animals and Human SocietyAcademic Press, pp. 103-131. http://dx.doi.org/10.1016/B978-0-12-805247-1.00006-X.

Schiefer, J., Lair, G.J., Blum, W.E.H., 2016. Potential and limits of land and soil for sustainable intensification of European agriculture. Agric. Ecosyst. Environ. 230, 283-293. http://dx.doi.org/10.1016/j.agee.2016.06.021.

Sekhon, B.S., 2014. Nanotechnology in agri-food production: an overview. Nanotechnol. Sci. Appl. 7, 31-53. http://dx.doi.org/10.2147/NSA.S39406.

Senthil Nathan, S., Young Choi, M., Yul Seo, H., Hoon Paik, C., Kalaivani, K., Duk Kim, J., 2008. Effect of azadirachtin on acetylcholinesterase (AChE) activity and histology of the brown planthopper Nilaparvata lugens (Stål). Ecotoxicol. Environ. Saf. 70, 244-250. http://dx.doi.org/10.1016/j.ecoenv.2007.07.005.

Servin, A.D., White, J.C., 2016. Nanotechnology in agriculture: next steps for understanding engineered nanoparticle exposure and risk. NanoImpact 1, 9-12. http://dx. doi.org/10.1016/j.impact.2015.12.002.

Seufert, V., Ramankutty, N., Foley, J.A., 2012. Comparing the yields of organic and conventional agriculture. Nature 485, 229-232. http://dx.doi.org/10.1038/ nature11069.

Shaheen, I., Ahmad, K.S., Zahra, T., 2017. Evaluating the fate of agrochemical through adsorption and desorption studies of chlorfluazuron in selected agricultural soils. J. King Saud Univ. Sci. http://dx.doi.org/10.1016/j.jksus.2017.12.005.

Sharp, R., 2013. A review of the applications of chitin and its derivatives in agriculture to modify plant-microbial interactions and improve crop yields. Agronomy 3, 757-793. http://dx.doi.org/10.3390/agronomy3040757.

Silva Brum, L.F., Emanuelli, T., Souza, D.O., Elisabetsky, E., 2001. Effects of linalool on glutamate release and uptake in mouse cortical synaptosomes. Neurochem. Res. 26, 191-194.

Simone, A., Andrea, L., Federica, R., 2009. Introduction. Managing the Uncertainty of Nanotechnology Across Boundaries and Scales. Stand Alone 1-6. https://doi.org/10. 3233/978-1-60750-022-3-1

Singh, R., Koul, O., Rup, P.J., Jindal, J., 2009. Toxicity of some essential oil constituents and their binary mixtures against Chilo partellus (Lepidoptera: Pyralidae). Int. J. Trop. Insect Sci. 29, 93. http://dx.doi.org/10.1017/S1742758409990087.

Sinha, K., Ghosh, J., Sil, P.C., 2017. New pesticides: a cutting-edge view of contributions from nanotechnology for the development of sustainable agricultural pest control. In: New Pesticides and Soil Sensors. Elsevier, pp. 47-79. http://dx.doi.org/10.1016/ B978-0-12-804299-1.00003-5.

Soderlund, D.M., Bloomquist, J.R., 1989. Neurotoxic actions of pyrethroid insecticides. Annu. Rev. Entomol. 34, 77-96. http://dx.doi.org/10.1146/annurev.en.34.010189. 000453.

Sola, P., Mvumi, B.M., Ogendo, J.O., Mponda, O., Kamanula, J.F., Nyirenda, S.P., Belmain, S.R., Stevenson, P.C., 2014b. Botanical pesticide production, trade and regulatory mechanisms in sub-Saharan Africa: making a case for plant-based pesticidal products. Food Secur. 6, 369-384. http://dx.doi.org/10.1007/s12571-014 0343-7.

Sola, P., Mvumi, B.M., Ogendo, J.O., Mponda, O., Kamanula, J.F., Nyirenda, S.P., Belmain, S.R., Stevenson, P.C., 2014a. Botanical pesticide production, trade and regulatory mechanisms in sub-Saharan Africa: making a case for plant-based pesticidal products. Food Secur. 6. http://dx.doi.org/10.1007/s12571-014-0343-7.

Spyrou, I.M., Karpouzas, D.G., Menkissoglu-Spiroudi, U., 2009. Do Botanical pesticides alter the structure of the soil microbial community? Microb. Ecol. 58, 715-727. http://dx.doi.org/10.1007/s00248-009-9522-z.

Squire, G.R., Hawes, C., Valentine, T.A., Young, M.W., 2015. Degradation rate of soil function varies with trajectory of agricultural intensification. Agric. Ecosyst. Environ. 202, 160-167. http://dx.doi.org/10.1016/j.agee.2014.12.004.

Stamou, G.P., Konstadinou, S., Monokrousos, N., Mastrogianni, A., Orfanoudakis, M., Hassiotis, C., Menkissoglu-Spiroudi, U., Vokou, D., Papatheodorou, E.M., 2017. The effects of arbuscular mycorrhizal fungi and essential oil on soil microbial community and N-related enzymes during the fungal early colonization phase. Microbiology 3, 938-959. http://dx.doi.org/10.3934/microbiol.2017.4.938.

Štefanidesová, K., Škultéty, L., Sparagano, O.A.E., Špitalská, E., 2017. The repellent efficacy of eleven essential oils against adult Dermacentor reticulatus ticks. Ticks TickBorne Dis. http://dx.doi.org/10.1016/j.ttbdis.2017.06.003.

Stokes, E., 2013. Demand for command: responding to technological risks and scientific uncertainties. Med. Law Rev. 21, 11-38. http://dx.doi.org/10.1093/medlaw/ fws 042 .

Strand, R., Kjølberg, K.L., 2011. Regulating nanoparticles: the problem of uncertainty Eur. J. Law Technol. 2 .

Tak, J.-H., Isman, M.B., 2017. Acaricidal and repellent activity of plant essential oil-derived terpenes and the effect of binary mixtures against Tetranychus urticae Koch (Acari: Tetranychidae). Ind. Crops Prod. 108, 786-792. http://dx.doi.org/10.1016/j. indcrop.2017.08.003.

Tambwe, M.M., Mbeyela, E.M., Massinda, B.M., Moore, S.J., Maia, M.F., 2014. Experimental hut evaluation of linalool spatial repellent agar gel against Anopheles gambiae sensu stricto mosquitoes in a semi-field system in Bagamoyo, Tanzania. Parasit. Vectors 7, 550. http://dx.doi.org/10.1186/s13071-014-0550-2.

Tavares, E.T., Schramm, F.R., Tavares, E.T., Schramm, F.R., 2015. The principle of precaution and the nano-techno-sciences. Rev. Bioét. 23, 244-255. http://dx.doi.org/10. 1590/1983-80422015232063.

Tian, J., Ban, X., Zeng, H., He, J., Chen, Y., Wang, Y., 2012. The mechanism of antifungal action of essential oil from dill (Anethum graveolens L.) on Aspergillus flavus. PLoS One 7, e30147. http://dx.doi.org/10.1371/journal.pone.0030147.

Tilman, D., Cassman, K.G., Matson, P.A., Naylor, R., Polasky, S., 2002. Agricultural sustainability and intensive production practices. Nature 418, 671-677. http://dx.doi. org/10.1038/nature01014.

Tong, F., Gross, A.D., Dolan, M.C., Coats, J.R., 2013. The phenolic monoterpenoid carvacrol inhibits the binding of nicotine to the housefly nicotinic acetylcholine receptor: inhibition by carvacrol of nicotine binding to the housefly nAchR. Pest Manage. Sci. 69, 775-780. http://dx.doi.org/10.1002/ps.3443.

Torney, F., Trewyn, B.G., Lin, V.S.-Y., Wang, K., 2007. Mesoporous silica nanoparticles deliver DNA and chemicals into plants. Nat. Nanotechnol. 2, 295-300. http://dx.doi. org/10.1038/nnano.2007.108.

Turgis, M., Han, J., Caillet, S., Lacroix, M., 2009. Antimicrobial activity of mustard essential oil against Escherichia coli O157:H7 and Salmonella typhi. Food Control 20, 1073-1079. http://dx.doi.org/10.1016/j.foodcont.2009.02.001.

Turpin, N., ten Berge, H., Grignani, C., Guzmán, G., Vanderlinden, K., Steinmann, H.-H., Siebielec, G., Spiegel, A., Perret, E., Ruysschaert, G., Laguna, A., Giráldez, J.V., Werner, M., Raschke, I., Zavattaro, L., Costamagna, C., Schlatter, N., Berthold, H., Sandàn, T., Baumgarten, A., 2017. An assessment of policies affecting sustainable soil management in Europe and selected member states. Land Use Policy 66, 241-249. http://dx.doi.org/10.1016/j.landusepol.2017.04.001.

United Nations, 2013. World Population Prospects: The 2012 Revision. Population Division, Dept of Economic and Social Affairs. 
Vachon, V., Laprade, R., Schwartz, J.-L., 2012. Current models of the mode of action of Bacillus thuringiensis insecticidal crystal proteins: a critical review. J. Invertebr. Pathol. 111, 1-12. http://dx.doi.org/10.1016/j.jip.2012.05.001.

Verma, M.L., 2017. Enzymatic Nanobiosensors in the agricultural and food industry. In: Ranjan, S., Dasgupta, N., Lichtfouse, E. (Eds.), Nanoscience in Food and Agriculture 4. Springer International Publishing, Cham, pp. 229-245. http://dx.doi.org/10. 1007/978-3-319-53112-0_7.

Verma, J.P., Jaiswal, D.K., Meena, V.S., Kumar, A., Meena, R.S., 2015. Issues and challenges about sustainable agriculture production for management of natural resources to sustain soil fertility and health. J. Clean. Prod. 107, 793-794. http://dx.doi.org/ 10.1016/j.jclepro.2015.04.130.

Vokou, D., 2007. Allelochemicals, allelopathy and essential oils: a field in search of definitions and structure. Allelopathy J. 9, 119-135.

Vokou, D., Chalkos, D., Karamanlidou, G., Yiangou, M., 2002. Activation of soil respiration and shift of the microbial population balance in soil as a response to Lavandula stoechas essential oil. J. Chem. Ecol. 28, 755-768. http://dx.doi.org/10. 1023/A:1015236709767.

Wakeling, E.N., Neal, A.P., Atchison, W.D., 2012. Pyrethroids and their effects on ion channels. In: Soundararajan, R.P. (Ed.), Pesticides - Advances in Chemical and Botanical Pesticides. InTech. http://dx.doi.org/10.5772/50330.

Wang, M., Chen, Y., Zhang, R., Wang, W., Zhao, X., Du, Y., Yin, H., 2015. Effects of chitosan oligosaccharides on the yield components and production quality of different wheat cultivars (Triticum aestivum L.) in Northwest China. Field Crops Res. 172, 11-20. http://dx.doi.org/10.1016/j.fcr.2014.12.007.

Werdin González, J.O., Gutiérrez, M.M., Ferrero, A.A., Fernández Band, B., 2014. Essential oils nanoformulations for stored-product pest control? Characterization and biological properties. Chemosphere 100, 130-138. http://dx.doi.org/10.1016/j. chemosphere.2013.11.056.

Wezel, A., Casagrande, M., Celette, F., Vian, J.-F., Ferrer, A., Peigné, J., 2014 Agroecological practices for sustainable agriculture. A review. Agron. Sustainable Dev. 34, 1-20. http://dx.doi.org/10.1007/s13593-013-0180-7.

Xing, K., Zhu, X., Peng, X., Qin, S., 2015. Chitosan antimicrobial and eliciting properties for pest control in agriculture: a review. Agron. Sustainable Dev. 35, 569-588. http:// dx.doi.org/10.1007/s13593-014-0252-3.

Xu, H.-X., Zheng, X.-S., Yang, Y.-J., Tian, J.-C., Lu, Y.-H., Tan, K.-H., Heong, K.-L., Lu, Z.X., 2015. Methyl eugenol bioactivities as a new potential botanical insecticide against major insect pests and their natural enemies on rice (Oriza sativa). Crop Prot. 72, 144-149. http://dx.doi.org/10.1016/j.cropro.2015.03.017.

Yang, G., Chen, C., Wang, Y., Peng, Q., Zhao, H., Guo, D., Wang, Q., Qian, Y., 2017. Mixture toxicity of four commonly used pesticides at different effect levels to the epigeic earthworm, Eisenia fetida. Ecotoxicol. Environ. Saf. 142, 29-39. http://dx. doi.org/10.1016/j.ecoenv.2017.03.037.

Yang, F.-L., Li, X.-G., Zhu, F., Lei, C.-L., 2009. Structural characterization of nanoparticles loaded with garlic essential oil and their insecticidal activity against Tribolium castaneum (Herbst) (Coleoptera: Tenebrionidae). J. Agric. Food Chem. 57, 10156-10162. http://dx.doi.org/10.1021/jf9023118.

Zhang, D., Yan, M., Niu, Y., Liu, X., van Zwieten, L., Chen, D., Bian, R., Cheng, K., Li, L., Joseph, S., Zheng, J., Zhang, X., Zheng, J., Crowley, D., Filley, T.R., Pan, G., 2016. Is current biochar research addressing global soil constraints for sustainable agriculture? Agric. Ecosyst. Environ. 226, 25-32. http://dx.doi.org/10.1016/j.agee. 2016.04.010. 